\section{Local Forms and Regional Distributions. Metallurgical Analysis of Late Bronze Age Objects from Bosnia}

\author{
Mario Gavranović \\ Mathias Mehofer
}

with contributions by

Aleksandar Jašarević

Ajla Sejfuli

\begin{abstract}
This paper discusses the first results of the archaeometallurgical investigation conducted in cooperation between the institutes OREA (Institute for Oriental and European Archaeology, Austrian Academy of Sciences) and VIAS (Vienna Institute for Archaeological Science, University Vienna) and the regional museums in Doboj and Travnik (Bosnia-Herzegovina). The 76 sampled artefacts are dated between the $13^{\text {th }}$ and $9^{\text {th }}$ centuries BC $(\mathrm{Ha} \mathrm{A} 1-\mathrm{Ha} \mathrm{B} 3)$. The spectrum of finds includes forms of supra-regional, regional and local distribution, originating from different contexts (settlements, graves and hoards). After the first analysis of 91 samples (metals and ores) using a scanning electron microscope (SEM-EDS) at the VIAS, a group of 30 archaeologically and metallurgically significant samples was additionally examined by ED-XRF analysis to determine the trace element concentration of each single artefact. The focus of this research is to determine whether the increase of copper based metal artefacts during the Late Bronze Age was stimulated by the use of local copper ore resources - since they were accessible during this time period - or if a long-range, European distribution network was used to cover the need for raw material. Furthermore, it should be examined whether locally distributed bronzes can be distinguished from supra-regional types, by not only typological differences but also regarding their metallurgical composition.
\end{abstract}

\section{Keywords}

Bosnia, bronze artefacts, exchange networks, metal trade, archaeometallurgical analyses, Late Bronze Age, Hallstatt period.

Zusammenfassung - Lokale Formen und regionale Verteilung. Metallurgische Analysen spätbronzezeitlicher Objekte aus Bosnien Im vorliegenden Beitrag werden die ersten Ergebnisse archäometallurgischer Untersuchungen vorgestellt, die im Rahmen einer Kooperation zwischen OREA (Institut für Orientalische und Europäische Archäologie), VIAS (Vienna Institute for Archaeological
Science, Universität Wien) und den Regionalmuseen in Doboj und Travnik (Bosnien-Herzegowina) entstanden sind. Die 76 beprobten Objekte datieren in die Zeitspanne zwischen dem 13. und dem 9. Jh. v. Chr. (Ha A1-Ha B3). Das Fundrepertoire umfasst Formen überregionaler, regionaler und lokaler Verbreitung aus unterschiedlichen Kontexten (Siedlung, Grab und Depot). Nach den ersten Analysen von 91 Proben (Metalle und Erze) mittels Rasterelektronenmikroskopie (SEM-EDS) am VIAS, wurde eine Gruppe von 30 archäologisch und metallurgisch signifikanten Objekten mittels Röntgenfluoreszenzanalyse (ED-XRF) analysiert, um die Konzentration der Spurenelemente jedes einzelnen Artefaktes zu bestimmen. Der Schwerpunkt der Untersuchungen lag auf der Frage, ob der beobachtbare metallurgische Aufschwung während der Spätbronzezeit durch den Abbau der lokalen, damals zugänglichen Kupfererze stimuliert wurde oder ob der Rohmaterialbedarf durch andere - europäische - Versorgungnetze gedeckt wurde.

\section{Schlüsselbegriffe}

Bosnien, Buntmetallgegenstände, Bronze, Austauschnetzwerke, Metallhandel, Archäometallurgie, Spätbronzezeit, Hallstattzeit.

\section{Introduction (M. Gavranović, M. Mehofer)}

The presented article introduces the preliminary outcome of a research project aimed at the archaeometallurgical and mining archaeological investigation in Bosnia-Herzegovina and the neighbouring regions in the western Balkans. ${ }^{1}$

1 The term western Balkans is used here to describe the western part of the Balkan Peninsula that includes most of Croatia, Bosnia-Herzegovina, Montenegro and Serbia. The frequent political use of the same term for the countries Albania, Macedonia, Montenegro, Serbia, Bosnia-Herzegovina and Croatia is a contemporary bureaucratic euphemism. 
Several decades ${ }^{2}$ have passed since the last studies have been carried out in this field, therefore it seems advisable to review and enhance the current state of research regarding the metal exchange networks of the Late Bronze Age in this part of the continent. This attempt will be made with the help of various chemical-analytical and archaeological methods, ${ }^{3}$ particularly with regard to the possible use of local copper ore deposits:, these are mainly found in the Central Bosnian Mountains; ${ }^{4}$ an area where several locations of prehistoric mining activities have been recorded.

The current state of research on this topic is insufficient and, since systematic studies are lacking, conclusions are based more on assumptions rather than on exact scientific results. This deficiency is particularly conspicuous for the advanced stage of the Late Bronze Age $\left(11^{\text {th }}-9^{\text {th }}\right.$ century BC) since archaeological evidence points to a significant increase of bronze industry in Bosnia. This manufacture growth included several production centres that apparently operated not only locally, but also regionally.

In total, 76 drill samples of bronze artefacts $\left(13^{\text {th }}\right.$ to $9^{\text {th }}$ centuries BC) and 15 ore samples available at the geological collection of the Travnik museum were taken and processed for further analysis at the VIAS archaeometallurgical laboratory. ${ }^{5}$ Additionally, 20 samples from artefacts, slags and ores found in Bosnia-Herzegovina and Serbia were also taken and analysed at VIAS.

2. Late Bronze Age Metallurgy in Bosnia (M. Gavranović, M. Mehofer)

\subsection{A Short Overview of the Previous Archaeometallurgical Research}

The last comprehensive overview regarding Bronze Age metallurgy in Bosnia-Herzegovina was made more than 40 years ago at a 1973 symposium dedicated to the history of mining and metallurgy in southeast Europe. ${ }^{6}$ Despite the clear statement by B. Čović about the necessity of advanced geological and chemical analysis in order to gain at least basic information regarding possible ore sources and

2 RadimskÝ 1897. - Katzer 1905. - ĆurČIĆ 1908. - Junghans, SAngmeister, Schröder 1960. - Junghans, SANgmeister, Schröder 1968a, b, c. - Junghans, Sangmeister, Schröder 1974. - Čović 1975. - Čović 1995.

3 Pernicka 2014.

4 Čović 1995. - Ramović 1999.

5 As a starting point for this project, a first journey was made in the fall of 2014 to the Bosnian region, during which the local museums of Doboj and Travnik were visited.

6 Čović 1999. ancient casting technology, almost nothing has been done in this field since then. It is somewhat paradoxical that more work regarding the local Bronze Age metallurgy was accomplished before, rather than after, the stated paper. Two objects from the pile-dwelling site Ripač on the Una River ( $10^{\text {th }}-7^{\text {th }}$ century BC) had already been chemically analysed in $1895 .{ }^{8}$ The bowl shaped ingot contained $44 \% \mathrm{~Pb}, 18 \% \mathrm{Cu}$ and $8 \%$ Sn, while 'metallic grains' were obviously bronze drops ( $\mathrm{Cu} 81 \%$, Sn 15 \%, Pb $0.2 \%$ ). Important to this early research stage is also the discovery of two presumably prehistoric mining shafts in the area of the Central Bosnian Mountains in the upper valley of the Vrbas River (Mračaj and Maškara); items found include grooved stone axes, bone tools, handmade pottery and charcoal. ${ }^{9}$ However, according to F. Katzer, it could not be determined which ore was actually exploited or during which time period, since the geological structure offers several possibilities (siderite, tetrahedrite) ${ }^{10}$ Some of the artefacts from these two shafts were eventually published in 1908 by V. Curčić and dated to the Late Bronze Age. ${ }^{11}$ This short article was the first attempt to correlate archaeological finds, Bronze Age metallurgy and local ore resources. At the time of publication, emphasis was already being placed on numerous casting mould finds from various Late Bronze Age settlements sites in central and northern Bosnia, ${ }^{12}$ as well as on the question of copper ore supply for the flourishing domestic workshops. According to Curčić, the two described shafts in central Bosnia were likely used for the mining of the copper-antimony ores, which were either cast in the nearby workshops or distributed further before processing. ${ }^{13}$ Since these early studies, the area of the Central Bosnian Mountains (geologically defined as Mid-Bosnian schist mountains) has been frequently cited in numerous archaeological papers as a potential ore source for Bronze Age metallurgy. ${ }^{14}$ These presuppositions were supported by geological investigations pointing to certain concentrations of copper ores, gold, silver and tin stone in this area ${ }^{15}$ as well as by historical sources that refer to mining during the Roman period and the Middle Ages. ${ }^{16}$

\footnotetext{
7 Čović 1999, 57.

8 RadimskÝ 1897, 329.

9 KATZER 1905.

10 KATZER 1905, 375.

11 ČURČIĆ 1908, 77.

12 Gavranović 2013, Fig. 2.

13 ČUnČIĆ 1908, 90.

14 Durman 1983. - Čović 1995. - Karavanić 2006. - Gavranović 2011. - BleČIĆ-KaVUR, JašAREvić 2013.

15 Jurković 1958. - Hrvatović 1999. - Ramović 1999. - Palinkaš, Šoštarić, Palinkaš 2008. - Jurković, Hrvatović 2014. 16 Pašalić 1954. - BASLER 1999. - BojanOvski 1999.
} 
Unfortunately, this promising initial stage of research during the time of the Austrian rule in Bosnia (1878-1914) was not followed by further studies in the later periods, especially with regard to Late Bronze Age finds (Ha A-Ha B). Within the pan-European Project SAM (Studien zu den Anfängen der Metallurgie), only three objects of this period from Bosnia were sampled, ${ }^{17}$ one axe of the so called 'Albanian-Dalmatian type' from the hoard Debelo Brdo I near Sarajevo ${ }^{18}$ and two heavy axes from Debelo Brdo (chance find $)^{19}$ and the depot Mačkovac in northern Bosnia. ${ }^{20}$ Results of the trace element analysis revealed that pieces from Debelo Brdo contained respectively $3.5 \%$ and $6.5 \%$ tin, while the find from Mačkovac was made of pure copper (Sn $0.18 \%, \mathrm{~Pb} 0.22 \%$ ); this suggests that the artefact should be described as an axe-shaped ingot rather than as a tool or weapon. ${ }^{21}$ Trace element analyses were also performed for the two objects from the Osredak hoard (northwestern Bosnia), which are dated to the end of the Late Bronze Age (Ha B3);22 unfortunately precise specification of the particular finds was not available. Both samples contained $89 \%$ $\mathrm{Cu}, 1 \% \mathrm{Sn}$ and - quite unexpectedly - $10 \% \mathrm{Fe}$. Analysis of the ore samples from the two previously mentioned shafts in central Bosnia, are also worthy of note and are presented almost 100 years after their discovery. ${ }^{23}$ The samples were, as previously assumed, identified as a copper-antimony fahlore (tetrahedrite).

Valuable contributions were made for the periods prior to the Late Bronze Age, such as trace element analysis of the Copper and Early Bronze Age objects from Bosnia-Herzegovina and Croatia ${ }^{24}$ as well as lead isotope analysis of the same samples. ${ }^{25}$ Considering the possible exploitation of the local copper antimony ores, it is important to underline that all samples from this study with higher antimony concentration also contained silver in notably higher amounts (100 timer greater) than the so far known ore samples from Bosnia. ${ }^{26}$ Even if the chemical composition of the initial ore can be changed significantly in the course of smelting and casting, it is nearly impossible that the silver amount increased to such a high percentage during processing. Finally, lead

17 Junghans, SAngmeister, Schröder 1968a, Nos. 2584, 2587, 2588.

18 Žeravica 1993, Pl. 11/107. - KöNig 2004, Pl. 58/1.

19 Žeravica 1993, Pl. 12/124.

20 Žeravica 1993, Pl. 13/127. - König 2004, Pl. 49/B/2.

21 Čović 1999, 78. - König 2004, 98.

22 KNEZ 1958, 258. - KÖNIG 2004, Pls. 59-61.

23 Čović 1995, Tab. 4.

24 Govedarica, Pernicka, Rittershofer 1995.

25 Begemann, SchmitT-STECKer 2005.

26 Begemann, SchmitT-Stecker 2005, 59. isotope analysis revealed that the signature of the analysed Early Bronze Age objects from Bosnia-Herzegovina and Croatia does not match any obtainable data from the identified deposits in Serbia, Bulgaria, Greece or Anatolia. ${ }^{27}$

\subsection{Late Bronze Age Settlements with Metallurgical Activities}

Finds of casting moulds, cores, crucibles, ingots and semi-finished objects are usually strong indicators of metallurgic activities within a settlement area. However, such objects do not necessarily signify the existence of permanent workshops, since some of the production locations could also have been of a temporary character. Moreover, most of the casting moulds from Bosnia were discovered in older excavations (before 1945) and therefore are not clearly assigned to the particular structure (house, pit) or layer. Nevertheless, it is striking that, judging by the typo-chronological classification of the manufactured artefacts, the majority of casting locations were not in use until the advanced phase of the Late Bronze Age, i.e. before the stage Ha B1 (11 ${ }^{\text {th }}$ century $\mathrm{BC}$ ). Thus, evidence of earlier metallurgical activities (Bz D-Ha A1) is surprisingly rare. ${ }^{28}$ Similar tendencies of an upsurge of bronze metallurgy in the advanced stages of the Late Bronze Age are also noticed in the neighbouring region of continental Croatia. ${ }^{29}$

Among the sporadic objects pointing to metallurgic activities during the time of $\mathrm{Bz} \mathrm{D}-\mathrm{Ha} \mathrm{A} 1$, the first one to be addressed is a half mould for socketed axes without a loop and with three V-shaped ribs from the Crkvina hilltop near Doboj. ${ }^{30}$ Fragmented bronze objects and ingots from this period were also discovered in the settlements of Topolovaca Bregovi ${ }^{31}$ and Sječkovo, ${ }^{32}$ both locations are situated in the plains along the Sava River in the northern part of the country. A symbolic representation of metal processing or craftsmanship from the same time span $\left(13^{\text {th }}-12^{\text {th }}\right.$ century $\mathrm{BC})$ is indicated through several apparently non-used tools (small anvils, bronze cores) from the depot Boljanić, - some $15 \mathrm{~km}$ east of Doboj - and one further bronze core from the depot Vidovice on the Sava bank. ${ }^{33}$ Some of the depots from Bosnia-Herzegovina dated to $\mathrm{Ha} \mathrm{A} 1$ also contained plane convex ingots, ${ }^{34}$ which are a frequent component of

\footnotetext{
27 Begemann, SchmitT-Stecker 2005, 60.

28 Gavranović 2013, Figs. 1-2.

29 Karavanić 2009, Figs. 41-44.

30 RadimskÝ 1893, 262. - ŽERAvica 1993, Pl. 32/436.

31 Belić 2010, Pl. 7/1-3.

32 Ludajić 2010, 136.

33 KÖNIG 2004, 49.

34 KÖNIG 2004, 90.
} 


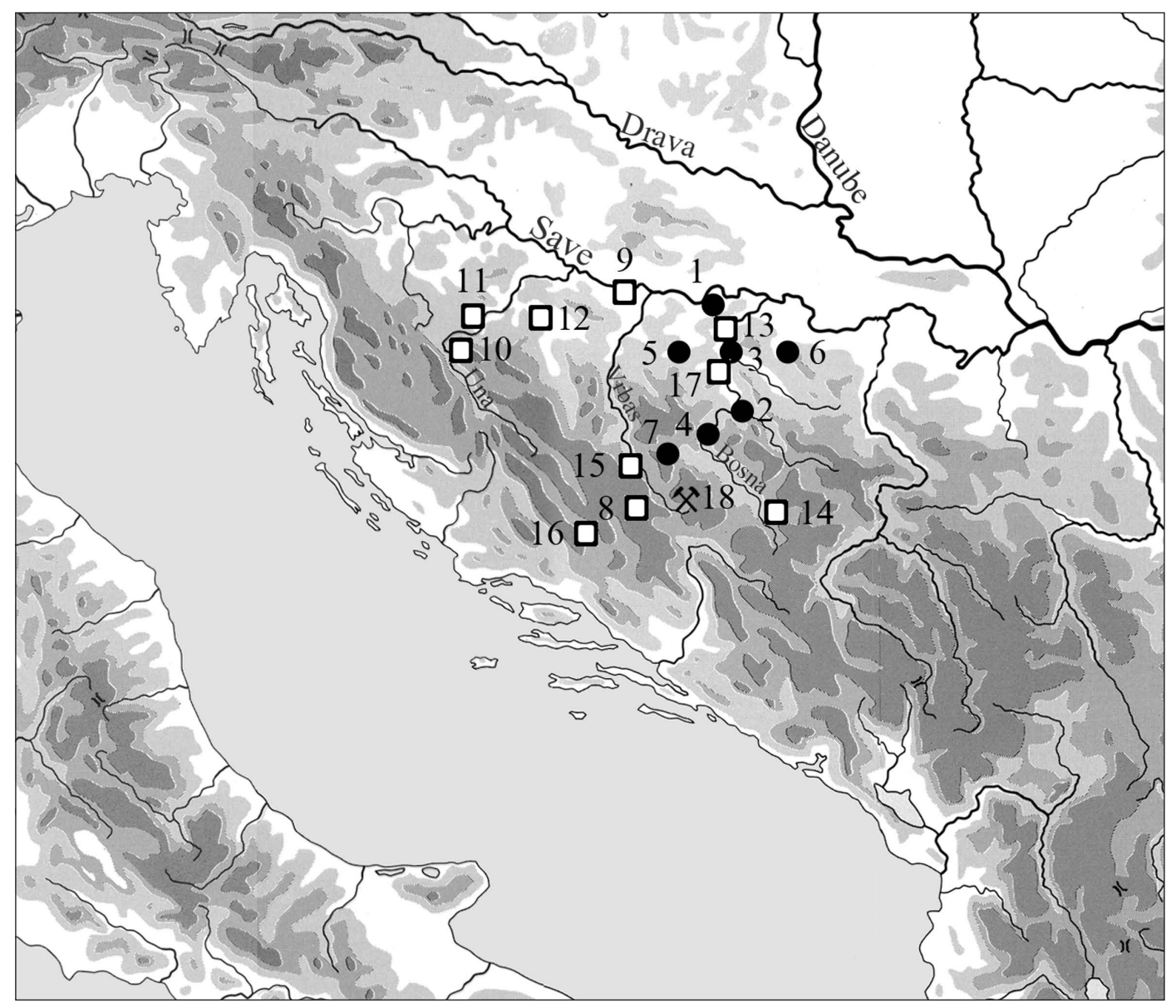

Fig. 1. Map of the Bosnian region (sampled objects derive from sites 1-7 [black dots]). -1. Kućišta. - 2. Majdan/ Ridžali. - 3. Grapska. - 4. Brezovo Polje. - 5. Derventa. - 6. Modriča. -7. Travnik and settlements with casting mould finds metallurgic activities (squares). - 8. Varvara. - 9. Donja Dolina. - 10. Ripač. - 11. Čungar. - 12. Kekića Glavica. -13. Pivnica. - 14. Debelo Brdo. - 15. Pod. - 16. Korita. - 17. Crkvina. - 18. Mračaj and Mačkara, two presumably prehistoric mining shafts (Graphics: M. Gavranović).

the hoards from this period in all adjacent territories of southeast Europe. ${ }^{35}$

The following periods $\mathrm{Ha}$ B1 and $\mathrm{Ha}$ B2/3 show a fundamentally different situation in which there are far more finds; this indicates a significant increase of metallurgical activities. The hilltop settlement of Varvara in the border zone between Bosnia and Herzegovina (Fig. 1) is one of the most evident sites with emerging bronze production - there are over 30 different casting moulds as well as several coneshaped cores and crucibles. ${ }^{36}$ All of these objects were found in 1899 in a layer that was ascribed to the $\mathrm{Ha}$ B1 period, af-

35 Vinski-Gasparini 1973, 28. - Petrescu-Dîmbovița 1977, 80. VAsić 1982, 274. - Mozsolics 1985, 37.

36 ĆurČić 1902, 99. - ŽERavica 1993, Pl. 47/683-692, 707. - Karavanić 2009, Fig. 46. - Gavranović 2011, Fig. 266. ter subsequent excavations. ${ }^{37}$ The same time span $\left(11^{\text {th }}-10^{\text {th }}\right.$ century BC) is also indicated by a typology of the casted objects. However, what is remarkable is the distribution of specific forms cast in Varvara, such as specific sword pommels with bronze analogies among weapons of northern Europe $^{38}$ or bronze scabbards whose closest parallels are in northern Dalmatia. ${ }^{39}$ The range of products from Varvara also includes several variants of vase-shaped pins, spearheads with a faceted middle part, chisels, wheel pendants and rings. ${ }^{40}$

37 Čović 1983, 294.

38 WANZEK 1997, 529.

39 Harding 1995, 75.

40 Gavranović 2013, Fig. 13. 
The same variety of bronze objects has also been produced in the riverbank settlement of Donja Dolina on the Sava River (Fig. 1). ${ }^{41}$ Although the exact context is not documented, some of the casted forms are fairly typo-chronologically determinable. One example is the mould for the lunate razor of the type Určice ( $\mathrm{Ha} \mathrm{B} 3)$; its main distribution is in the eastern part of central Europe between the Austrian part of Styria, and Moravia and Bohemia. ${ }^{42}$ Another specific object produced in Donja Dolina from the same pe$\operatorname{riod}(\mathrm{Ha} \mathrm{B} 3)$ and with similar distribution is the pin with a small, vase-shaped head. ${ }^{43}$ Cast at the same site are also some bronze forms typical for the area of the western Balkans, like the small undecorated socketed axes with a thickened or fluted mouth. ${ }^{44}$

Intensive casting activity took place at the previously mentioned pile dwelling site Ripač on the Una River in western Bosnia (Fig. 1). Beside ingots and bronze drops, early excavations yielded 17 casting moulds and numerous cores, among these there were three moulds for small undecorated socketed axes with a thick rounded mouth and a low-placed loop. ${ }^{45}$ Axes of this shape are a characteristic regional type for the end of the Late Bronze Age (Ha B3). Corresponding bronze finds have been documented mostly at surrounding sites of western and northwestern Bosnia and Croatia. ${ }^{46}$ Some of the moulds from Ripač were also used for the casting of multiple bars (10 cm long), probably with an ingot function and for small $(8 \mathrm{~cm})$ spearheads and triangular and disc-shaped pendants. ${ }^{47}$ Further finds of casting moulds (small undecorated axes, spear heads) and clay cores were identified in the nearby hilltop settlement of Čungar near Cazin. ${ }^{48}$

Another remarkable find is that of two moulds for the two different types of facetted spearheads, found at Pivnica near Odžak in northern Bosnia (Fig. 1). ${ }^{49}$ The moulds were found together with decorated pottery (incised horizontal, undulated and zigzag lines), which is typical for the settlements of the period between $\mathrm{Ha}$ B1 and $\mathrm{Ha}$ B3 in this area..$^{50}$ The backside of one of the two moulds was also used for the

41 Truhelka 1904. - Marić 1964. - Žeravica 1993, Pl. 22/289-292. - Gavranović 2013, Fig. 5.

42 Jockenhövel 1971, 213. - Weber 1996, 247.

43 Ř́́hovský 1983, 44. - Gavranović 2013, Fig. 6.

44 WanZeK 1989, 166. - ŽERavica 1993, Pl. 22/289-292.

45 RadimskÝ 1897, Pl. 21/63-69; Pl. 22/76. - ĆurČIĆ 1908, Pls. 3/22; 4/13-14. - ŽERavica 1993, Pl. 22/284-287.

46 WanzeK 1989, 77. - ŽErenavica 1993, Pls. 21-23. - König 2004,

132. - Gavranović, JašAREvić 2016, Map 5.

47 Radimský 1897, Pl. 21/68. - Ćurčić 1908, Pl. 3/20.

48 Čović 1983, 4 - Žeravica 1993, Pl. 46/675-679.

49 Benac 1967, 155.

50 Gavranović 2011, Fig. 254. casting of small, socketed hammers. ${ }^{51}$ Bronze finds which correspond with the facetted spearheads are appearing in depots of the $10^{\text {th }}$ and $9^{\text {th }}$ centuries BC in Bosnia-Herzegovina and Croatia. Of particular note are weapons from Ometala in Herzegovina, ${ }^{52}$ Matijevići on the Croatian bank of the Una River, ${ }^{53}$ as well as from Lučica in central Bosnia. ${ }^{54}$

Multiple casting moulds, bronze ingots and slags were also collected amongst dislocated material from the hilltop settlement of Debelo Brdo near Sarajevo (spearheads, dagger and bars) and Radmanići near Banja Luka (pin with bowl-shaped head). ${ }^{55}$ Repeatedly quoted, but not published or specified, are casting moulds from the settlements of Kekića Glavica in northwestern Bosnia, Korita in southwestern Bosnia, and Pod in central Bosnia; all sites have been dated between the $11^{\text {th }}$ and $9^{\text {th }}$ centuries BC (Fig. 1). ${ }^{56}$

Despite the fact that most of the named settlements were investigated with outdated archaeological methods, it is more than obvious that bronze casting activity in Bosnia gained new momentum from the time of $\mathrm{Ha}$ B1, with a number of sites producing both for local requirements as well as for the supra-regional exchange network. Combined with the intensity of production, there is also the appearance of specific, local forms of jewellery and weaponry with limited distribution within one or two neighbouring regions. ${ }^{57}$ However, due to the lack of archaeometallurgical analysis, the technological background of the bronze industry upsurge in the western Balkans remains unknown. Hence, the following presented trace element analysis is the first contribution towards a metallurgical understanding of the bronze objects from Bosnia-Herzegovina, dated to the Late Bronze Age.

3. Cultural and Chronological Background of the Sampled objects (M. Gavranović, M. Mehofer, A. Jašarević, A. Sejfuli)

The sampled objects (see Fig. 1 for the distribution) are divided in four chronological groups, corresponding to the following stages: $\mathrm{Ha} \mathrm{A} 1, \mathrm{Ha} \mathrm{A} 2-\mathrm{Ha} \mathrm{B} 1, \mathrm{Ha} \mathrm{B} 1$, and $\mathrm{Ha}$ B3 (Tabs. 1-2). ${ }^{58}$ The definition of the intermediate group $\mathrm{Ha}$ A2-Ha B1 was necessary because of the hoard from Brezovo Polje that contained a mixture of the typologically older finds such as sickle and long socketed axes with

51 ŽERavica 1993, Pl. 41/597.

52 König 2004, Pl. 67.

53 Vinski-Gasparini 1973, Pl. 129.

54 König 2004, Pl. 59/A.

55 Gavranović 2013.

56 Čović 1983, 75.

57 WANZEK 1989, 72. - Gavranović in press, Figs. 3-7. 


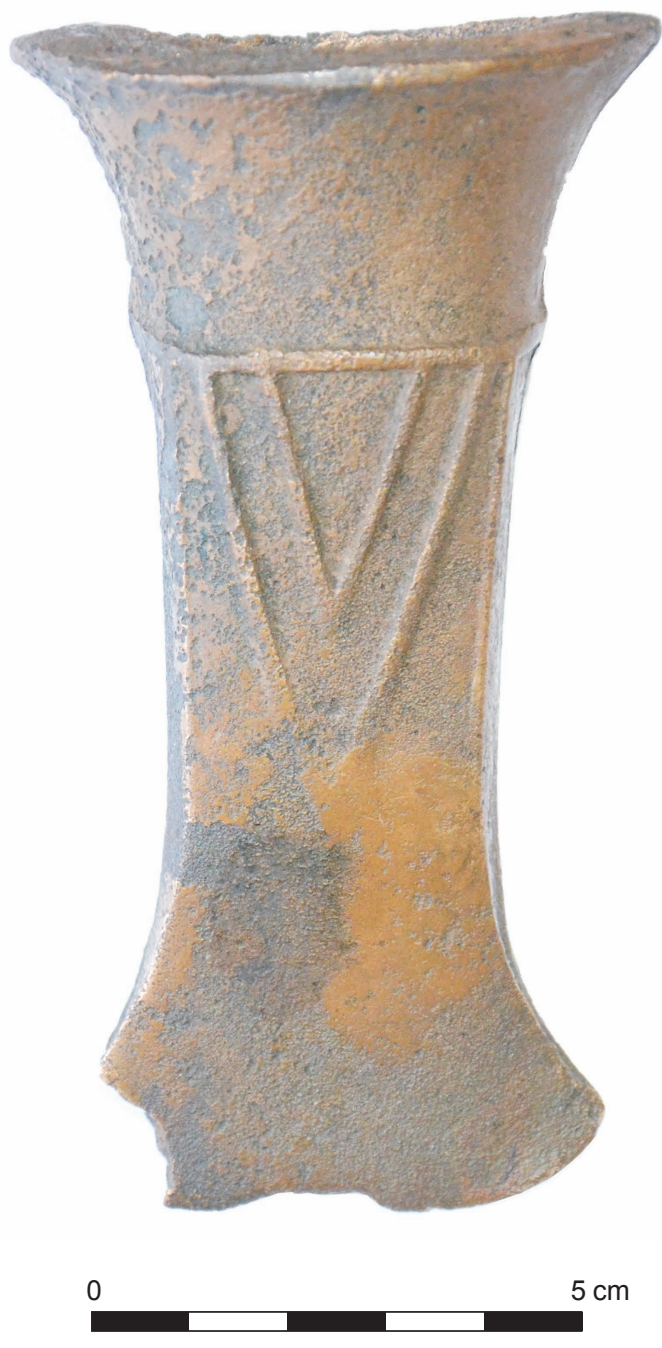

Fig. 2. Sampled socketed axe from Kućišta (Inv. no. 1793, Museum Doboj, MA - 152351) (Photo: M. Gavranović, M. Mehofer).

multiple V-ribs with younger objects such as small axes with a winged-like ornament or socketed axes with Y-ribs. ${ }^{59}$ Except for jewellery pieces from the destroyed graves in Travnik (Tab. 2), all other finds were discovered from a singular or collective deposition.

\subsection{Ha A1-Group}

The first chronological group contains forms typical of the older stage of the Urnfield Culture, with the main occurrence in numerous depots in the adjacent territories of the southern Carpathian Basin. In Bosnia-Herzegovina, depots of this time are found mainly along the Bosna River as a key north-south communication route between the plains of

59 KÖNIG 2004, 92. the Carpathian Basin and the mountain region of the western Balkans. ${ }^{60}$

A typical example of a hoard from this time is that of Kućišta with four sampled objects in the analysed series (Tab. 2). The first one is a socketed axe with a funnel-like mouth and no loop, decorated with two V-ribs hanging on one horizontal rib (Fig. 2). ${ }^{61}$ Axes of this type are one of the more significant bronze objects from the $\mathrm{Ha} \mathrm{A} 1$ period, ${ }^{62}$ analogies have been found in contemporary depots from northern Croatia ${ }^{63}$ and Serbia, ${ }^{64}$ Hungary, ${ }^{65}$ Transylvania, ${ }^{66}$ and Slovakia. ${ }^{67}$ A similar distribution area can also be identified for the socketed axes with a profiled mouth, which is the second sampled piece from Kućišta. ${ }^{68}$ Comparable finds are known from the nearby Boljanić hoard close to Doboj, ${ }^{69}$ but also from the following depots: Nova Bingula, ${ }^{70}$ Jakovo, ${ }^{71}$ Brestovik I, Brestovik V $\mathrm{V}^{72}$ and Rudnik ${ }^{73}$ in northern Serbia, Kupinovo $^{74}$ and Poljanci $\mathrm{I}^{75}$ in Croatia, Debeli $\mathrm{Vrh}^{76}$ in Slovenia, and Palotabozsok and Rinyaszentkirály in southern Hungary. ${ }^{77}$ Another characteristic type of the $\mathrm{Ha}$ A1 period from Kucišta, with an almost equal territorial distribution, is the spearhead with short incised lines around the socket. ${ }^{78}$ The closest parallels were, again, found in the neighbouring depots from Croatia, Serbia, Slovenia and Hungary. ${ }^{79}$ The

60 KöNIG 2004, Pl. 79.

61 Inv. no. 1793 (Museum Doboj), MA-152351; ŽEravica i 993, Pl. 32/434 ('Močila Gornja'). - KöNIG 2004, Pl. 1/15.

62 WANZEK 1989, 115.

63 Vinski-Gasparini 1973, Pl. 27/11 (Otok-Privlaka); Pl. 31/8 (Tenja); Pl. 62/7 (Brodski Varoš); Pl. 67/1 (Podcrkavlje); Pl. 78/3 (Budinšćina).

64 Vinski-Gasparini 1973, Pl. 84/7 (Bingula Divoš). - Popović 1994, Pl. 8/1 (Dobrinci).

65 Mozsolics 1985, Pl. 4/24 (Siógrád); Pl. 47/1 (Pécs); Pl. 60/7 (Peterd).

66 Petrescu-Dîmboviţa 1977, Pl. 194/15 (Spălnaca II); Pl. 149/5

(Guşterița II).

67 Novotiná 1970, Pl. 37/654-655.

68 Inv. no. 1794 (Museum Doboj), MA-152352; ŽEravica 1993, Pl. 25/339 ('Močila Gornja'). - KöNIG 2004, Pl. 2/17. - For a general distribution see WanzeK 1989, Pl. 28. - HANSEN 1994, Fig. 107.

69 KöNIg 2004, Pl. 15/19-21.

70 Popović 1975, Pl. 34/2.

71 TASić 1975, Pl. 27/13.

72 Garašanin 1975a, Pls. 8/7; 17/1.

73 Garašanin 1975b, Pl. 78/2.

74 Balen-Letunić 1988, Pl. $3 / 6$

75 Miklik-Lozuk 2009, 56.

76 Čerče, ŠInkOvec 1995, Pl. 95/63.

77 Mozsolics 1985, Pls. 70/15; 97/8.

78 Inv. no. 1804 (Museum Doboj), MA-152353; KöNIg 2004, Pl. 1/11.

79 Hansen 1994, Fig. 41. - KÖNIg 2004, 73 and Pl. 81. - Gavranović 2011, Fig. 40. - Blečić-Kavur, Jašarević 2014, Fig. 7. - Vasić 2015,51 . 


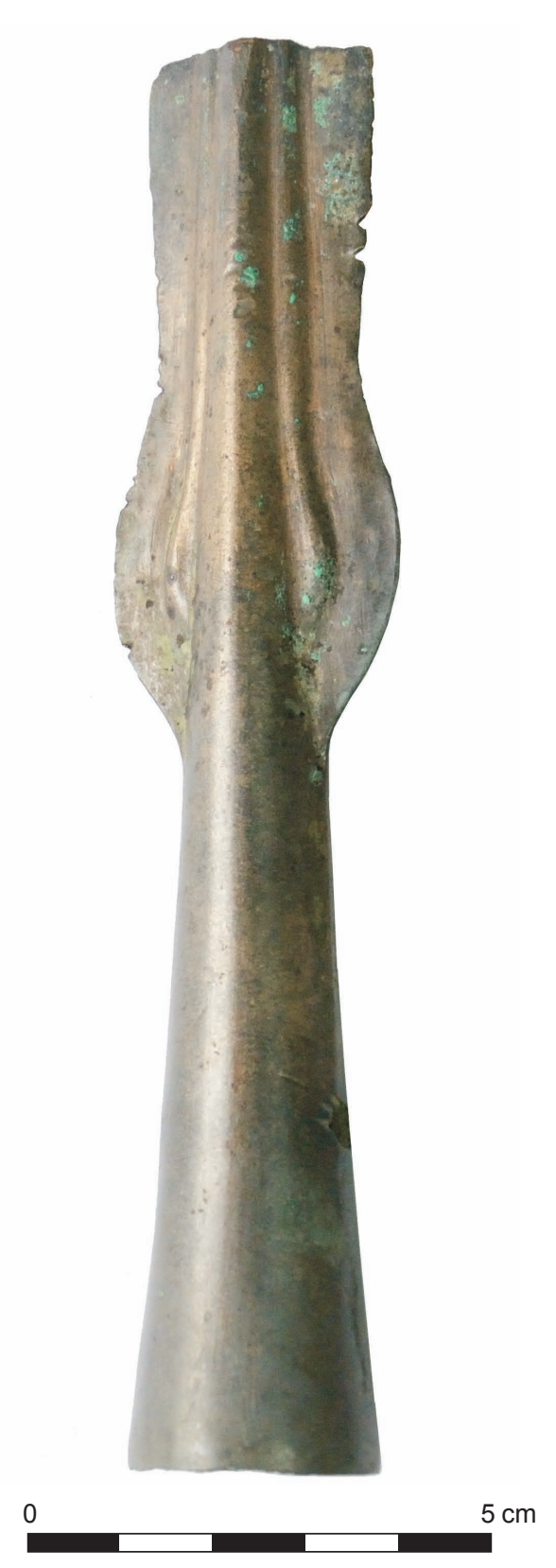

Fig. 3. Sampled spear head from Majdan-Ridžali (Inv. no. 5354, Museum Doboj, MA - 152355) (Photo: M. Gavranović, M. Mehofer).

last sampled object from Kućišta is the socketed chisel with a concave blade, decorated with hanging triangle ornamentation under the mouth. ${ }^{80}$ One similar, yet undecorated, piece was found in the mentioned depot Boljanić near Doboj. ${ }^{81}$ Other chisels of this type occur mostly in the depots of the

80 Inv. no. 1796 (Museum Doboj), MA-152359; Žeravica 1993, Pl. 43/630 ('Močila Gornja'). - KöNIG 2004, Pl. 2/20.

81 KöNIG 2004, Pl. $18 / 49$. older Urnfield Culture on the southern edge of the Carpathian Basin, in the area between the rivers Drava and Sava. ${ }^{82}$

Two of the sampled objects from the oldest chronological group were part of the depot Majdan-Ridžali on the middle course of the Bosna River. The grip-tongue sword with a serrated ricasso is ascribed to the specific regional variant of the Reutlingen type ${ }^{83}$ and is named after the find from Staro Topolje near Slavonski Brod in Croatia. ${ }^{84}$ Other swords of this variant are documented from the depots of the stage Ha A1 in Slavonski Brod II ${ }^{85}$ and Debeli Vrh (Slovenia), ${ }^{86}$ as well as singular finds from Ritiševo near Vršac in Serbian Banat and from Dolina near Nova Gradiška in northern Croatia. ${ }^{87}$ The second analysed object from Majdan-Ridžali is the spearhead with a ribbed, profiled blade (Fig. 3), ${ }^{88}$ which is a widely distributed weapon type within the time span of $\mathrm{Bz} \mathrm{D}-\mathrm{Ha} \mathrm{A} 1 .^{89}$ The best analogies for the sampled piece from Bosnia again derive from the depots in Hungary, ${ }^{90}$ Croatia, ${ }^{91}$ and Serbia. ${ }^{92}$

Added to the chronological group Ha A1 are: one griptongue sickle from Brezovo Polje as well as another sickle and one socketed axe from Grapska. Although both depots contained distinctly younger finds, these three objects reveal clear typological features of the older stage of the Urnfield Culture. The sickle from Brezovo Polje ${ }^{93}$ has three horizontal ribs on the grip, which can be associated with the Uioara 2a type, as defined for the territory of Romania, Austria and Serbia, with numerous parallels in the depots of the $\mathrm{Ha}$ A1 period. ${ }^{94}$

The sickle from Grapska ${ }^{95}$ is related to the widespread type Uioara 8. The nearest comparable finds are known from the $\mathrm{Ha} \mathrm{A} 1$ depots in the adjacent territory of northern

82 Hansen 1994, 151.

83 Inv. no. 5350 (Museum Doboj), MA-152354; BleČIĆ-Kavur, JAŠAREVIĆ 2014, Fig. 3; Pl. 1/1.

84 HaRding 1995, 38.

85 Clausing 2003, Fig. 1/1.

86 ČerČE, ŠInKOvec 1995, Pl. 62/23.

87 Harding 1995, 39 and Pl. 13/92, 94.

88 Inv. no. 5354 (Museum Doboj), MA-152355; Blečić-Kavur, JAŠAREVIĆ 20I 4 , Pl. 1/3.

89 HANSEn 1994, 66-67. - VAsić 2015, 53.

90 Mozsolics 1985, Pl. 1/14 (Bükkaranyos I); Pl. 3/9 (Bükkaranyos II).

91 Vinski-Gasparini 1973, Pl. 31/13 (Tenja); Pl. 50/7 (Gornja Vrba); Pl. 67/15 (Podcrkavlje).

92 VAsić 2015, Pl. 11/154-158; Pl. 12/159-161.

93 Inv. no. 2752 (Museum Travnik), MA-152336; KöNig 2004, Pl. 30/20.

94 Petrescu-Dîmboviţa 1978, 54 and Pl. 176/358 (Uiora de Sus). - Mozsolics 1985, Pl. 67/1 (Birján); Pl. 88/10 (Bakóca). - Primas 1986, 91. - VASIĆ 1994, 41.

95 Inv. no. 1743 (Museum Doboj), MA-152328; KöNIG 2004, Pl. 77/9. 
Serbia. ${ }^{96}$ The socketed axe with a thickened mouth and three $\mathrm{V}$-ribs without a loop from Grapska ${ }^{97}$ is also a characteristic form for the period between the $13^{\text {th }}$ and $11^{\text {th }}$ centuries BC. ${ }^{98}$ Considering the specific decoration and shape, the sampled axe is very similar to the three axes from the depot Motke near Kakanj in central Bosnia, dated to the end of the stage $\mathrm{Ha}$ A $1 .{ }^{99}$ In the surrounding regions, axes of this type are also known mostly from the depots of the stage $\mathrm{Ha}$ A1. ${ }^{100}$

\subsection{Ha A2/Ha B1-Group}

The transition group $\mathrm{Ha} \mathrm{A} 2 \mathrm{Ha}-\mathrm{B} 1$ includes eight sampled socketed axes from Brezovo Polje with typologically ambiguous attributes and one short spearhead from the same depot. The dating of Brezovo Polje in the younger stage of the Urnfield Culture (Ha B1), as proposed in some earlier studies, ${ }^{101}$ seems however somewhat disputable, since most of the objects are still displaying traditional typological features of the older periods. The four axes with a thickened or lightly faceted mouth, vertical loop, and three hanging V-ribs are a good example. ${ }^{102}$ Axes of very similar shape and decorations are also appearing in the above mentioned depot of the late $\mathrm{Ha}$ A1 period from Motke. ${ }^{103}$ Corresponding pieces from neighbouring regions are also dated to the $\mathrm{Ha}$ A1 stage. ${ }^{104}$ However, one of the four axes from Brezovo Polje ${ }^{105}$ lacks two small lateral holes for the fixture of the cores, which is one of the main technical characteristics of almost all socketed axe types from the older Urnfield period. ${ }^{106}$ A typologically younger feature on the four sampled axes is the low position of the loop under the mouth; this is

96 Popović 1975, Pl. 42/8 (Dobrinci). - Popović 1994, Pl. 25/1 (Donji Petrovci). - Vasić 1994, Nr. 252-280. - Jovanović 2010, Pl. 5/18 (Markovac-Grunjac).

97 Inv. no. 1737 (Museum Doboj), MA-152345; KöNIG 2004, Pl. 37/3.

98 vON BRUNN 1968, 52. - WANZEK 1989, 115. - GAvranović 2011, 130.

99 KÖNIG 2004, Pl. 24/7-8.

100 VinSKi-GASPARINI 1973, Pl. 62/11 (Brodski Varoš). -JACANOviĆ, RADOJČIĆ 2003, Pl. 1/1 (Šetonje).

101 Vinski-Gasparini 1983, 662. - ŽEravica 1993, 101-104.

102 Inv. no. 2737 (Museum Travnik), MA-152333; ŽEravica 1993, Pl. 28/378. - KÖNIG 2004, Pl. 29/9; Inv. no. 2741 (Museum Travnik), MA-152332; ŽEravica 1993, Pl. 28/381. - König 2004, Pl. 29/4; Inv. no. 2742 (Museum Travnik), MA-152329; ŽEravica 1993, Pl. 28/382. - KöNig 2004, Pl. 29/5; Inv. no. 2744 (Museum Travnik), MA-152334; ŽEravica 1993, Pl. 28/384. - König 2004, Pl. 29/10.

103 KÖNIG 2004, Pl. 25/16.18.

104 Vinski-Gasparini 1973, Pl. 73/5 (Mačkovac). - Moszolics 1985, Pl. 70/10 (Palotabozsok); Pl. 97/4 (Rinyaszentkirály); Pl. 107/1 (Lengyeltóti); Pl. 111/9 (Szentgáloskér). - Borić 1997, Pl. 5/45 (Futog). - Miklik-Lozuk 2000, Pl. 55/21.

105 Inv. no. 2737 (Museum Travnik), MA-152333; ŽEravica 1993,

Pl. 28/378. - KÖNIG 2004, Pl. 29/9.

106 MAYer 1977, 207. - KöNIg 2004, 99. a characteristic technological trait of the socketed axes from a younger ( $\mathrm{Ha} \mathrm{B} 1)$ stage and especially of the late stage $(\mathrm{Ha}$ B3) of the Urnfield period. ${ }^{107}$

The combination of distinctive older and younger typological elements can also be noted for the further three axes from Brezovo Polje with Y-ribs (Fig. 4). ${ }^{108}$ The decoration, a slightly trapezoidal shape of the blade and flat edge, certainly indicates a date in $\mathrm{Ha} \mathrm{B} 1 ;{ }^{109}$ however one of the axes (Fig. 4, right) has still two lateral holes, which is, as already stated, an element predominantly characteristic for the axes of the Ha A1 period.

The slender axe from Brezovo Polje with a wing-like ornament and trapezoidal, moderately spreading blade was also sampled. ${ }^{110}$ Analogies to this piece are documented in the depots of the Ha A1 stage in neighbouring Croatia ${ }^{111}$ and in several Hungarian depots of the Ha A2 stage (Gyermely horizon). ${ }^{112}$ Axes with the same ornament but with a much wider blade come from Mačkovac on the Bosnian bank of the Sava River ${ }^{113}$ and from Kapelna in northern Croatia. ${ }^{114}$ Both are dated to an even younger period ( $\mathrm{Ha} \mathrm{B} 1)$. The chronological uncertainty also concerns the small spearhead ${ }^{115}$ from Brezovo Polje; it has parallels pointing to both older and younger stages of the Urnfield Culture.

Hence, it is concluded that, according to typological criteria, the ultimate dating of the depot Brezovo Polje to the older or younger Urnfield stages is actually not supported by any convincing arguments. Due to the lack of other, more reliable methods, the proposed date to the intermediate period $\mathrm{Ha} \mathrm{A} 2-\mathrm{Ha} \mathrm{B} 1$ or in the time between the end of the $12^{\text {th }}$ and first half of the $11^{\text {th }}$ century BC seems most acceptable. ${ }^{116}$

\subsection{Ha B1-Group}

Three of the sampled objects are dated to the younger stage of the Urnfield Culture (Ha B1). Rather unusual for Bosnia-Herzegovina and surrounding countries are trapezoidal

107 KÖNIG 2004, 130.

108 Inv. no. 2747 (Museum Travnik), MA-152330; ŽEravica 1993, Pl. 29/386. - KöNIg 2004, Pl. 30/11; Inv. no. 2749 (Museum Travnik), MA-152228; ŽERAvica 1993, Pl. 29/387. - KöNig 2004, Pl. 30/12; Inv. no. 2750 (Museum Travnik), MA-152331; ŽEravica 1993, Pl. 29/388. - KÖNIG 2004, Pl. 30/14.

109 von Brunn 1968, 47. - MAYer 1977, 54. - KÖNIg 2004, 101.

110 Inv. no. 2751 (Museum Travnik), MA-152335; ŽEravica 1993, Pl. 37/505. - KÖNIG 2004, Pl. 30/17.

111 Vinski-Gasparini 1973, Pl. 61/10 (Brodski Varoš). - HARDing 1995, Pl. 62/24 (Slavonski Brod).

112 Mozsolics 1985, Pl. 243/23 (Székesfehérvár); Pl. 264/4-5 (Debrecen III).

113 KÖNIG 2004, Pl. 49B/4

114 VinsKi-GasParini 1973, Pl. 110/ 9.

115 Inv. no. 2754 (Museum Travnik), MA-152337; KöNIG 2004, 29/1.

116 KÖNIG 2004, 27. 


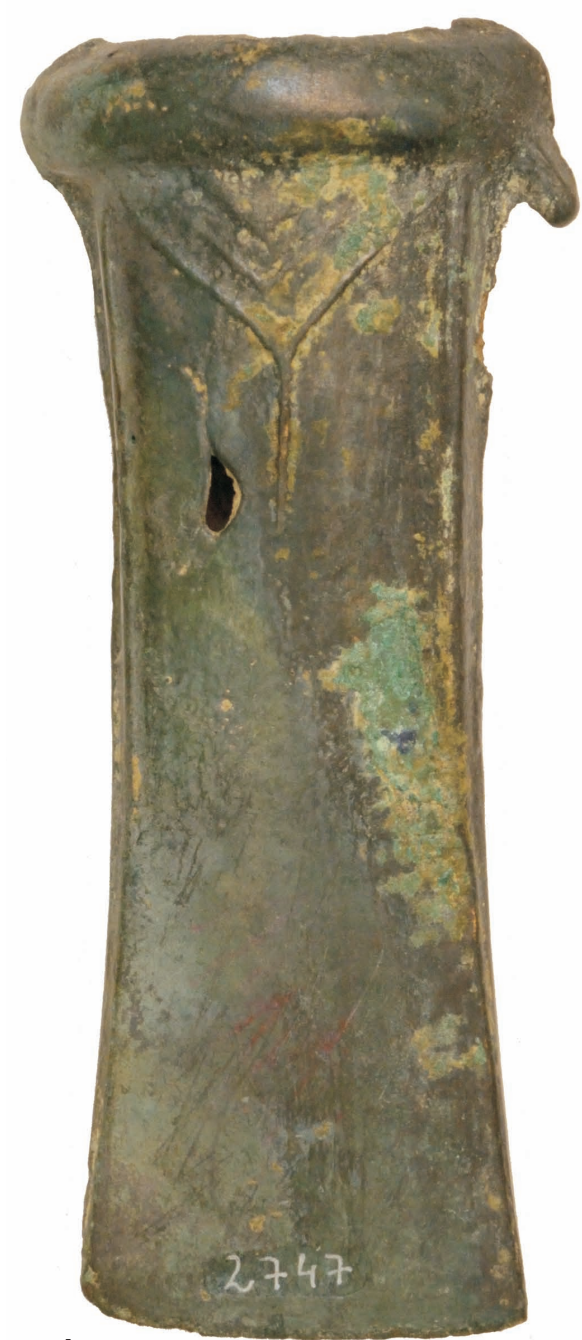

A

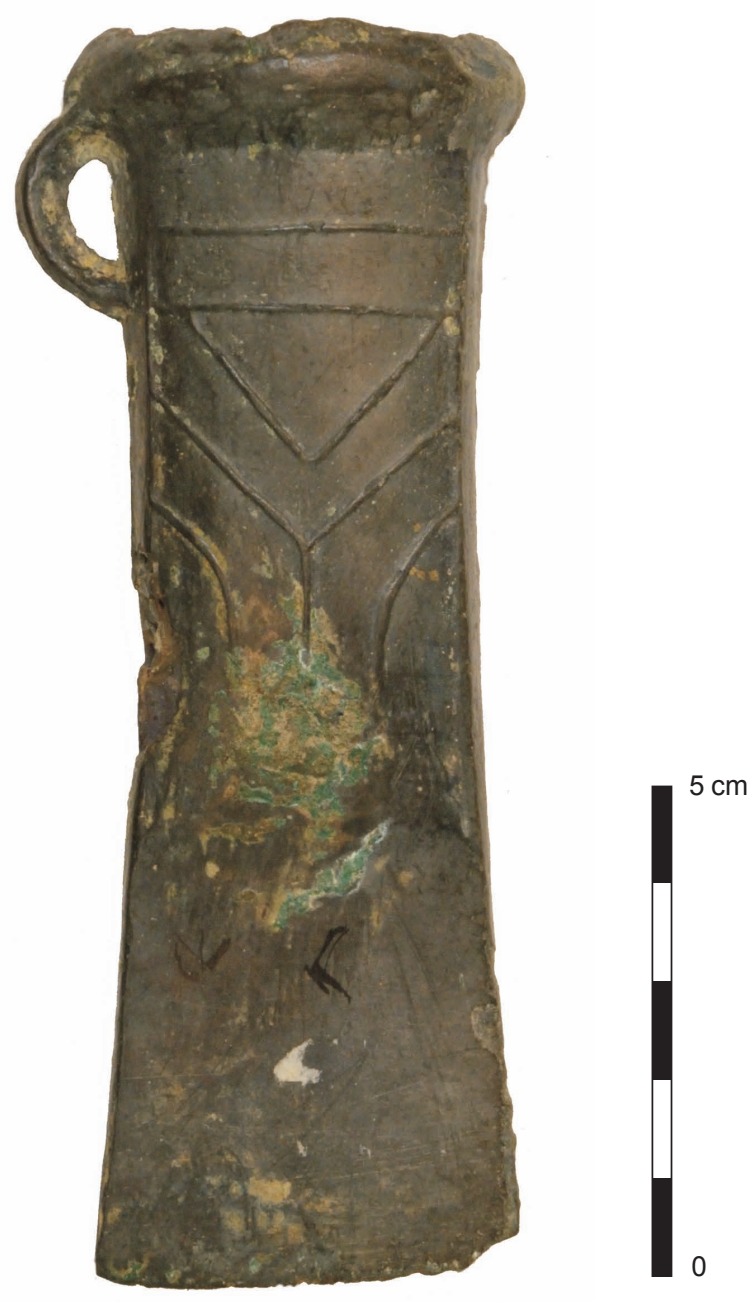

B

Fig. 4. Sampled socketed axes from Brezovo Polje (A: Inv. no. 2747, MA - 152330 and B: Inv. no. 2750, MA - 152331, both from Museum in Travnik) (Photos: M. Gavranović, M. Mehofer).

socketed axes with horizontal ribs and four hanging V-ornaments, represented through two sampled pieces from Grapska. ${ }^{117}$ The typologically most equivalent axes are known from the depots of the Horizon Moigrad-Tăuteu (Ha B1) in Transylvania. ${ }^{118}$

The axe from Derventa in northern Bosnia has a trapezoidal blade, a straight edge, and a combination of horizontal and Y-ribs. ${ }^{119}$ It represents one of the most significant

117 Inv. no. 1738-1739, (Museum Doboj), MA-152343-152344; Žeravica 1993, Pl. 28/375-376. - KöNIg 2004, Pl. 74/4-5.

118 Petrescu-Dîmboviţa 1977, Pl. 315/7 (Săcuieni); Pl. 326/3 (Spălnaca I); Pl. 329/10 (Tăuteu).

119 Inv. no. 4605 (Museum Doboj), MA-152356; Gavranović, JAŠAREVIĆ 2016, Fig. 5/1. - The axe was found together with another fragmented axe of the same type and can therefore probably be considered as part of the depot. bronze types of the $\mathrm{Ha}$ B1 stage in the Carpathian Basin and central Europe. ${ }^{120}$ Considering the size, shape and decoration of the sampled piece, the finds which resemble the Derventa axe the most, come from the Bokavić depot some $30 \mathrm{~km}$ to the east. ${ }^{121}$ Similar axes are, however, also known from more distant places like Jászkarajenő and Debrecen ${ }^{122}$ in Hungary or Zagon ${ }^{123}$ and Dridu ${ }^{124}$ in Romania.

120 Hampel 1886, 11. - von Brunn 1968, 47. - Novotná 1970, 85. - Vinski-Gasparini 1973, 142. - Kemenzei 1984, 53. - Mozsolics 1985, 26. - WANZEK 1989, 106. - Ř́́HOvskÝ 1992, 206. - KöNIg 2004, 101. - Tarbay 2014, Fig. 10.

121 KÖNIG 2004, Pl. 38/29.

122 Mozsolics 1985, Pls. 250/12; 265/47.

123 Petrescu-Dîmboviţa 1977, Pl. 338/9.

124 ENĂCHIUC 1995, Fig. 1/8. 


\subsection{Ha B3-Group}

Characteristic for the late Urnfield period ( $\mathrm{Ha} \mathrm{B} 3)$ is the appearance of the local bronze types with a geographically restricted distribution between the Adriatic coast in the south and the Sava River in the north. The previous, very clear typo-technological affiliation with the Carpathian Basin seems to be almost completely intermittent throughout the course of the $10^{\text {th }}$ century BC. As described in the previous chapter, this period is characterised by the emergence of new production locations in Bosnia-Herzegovina (Varvara, Ripač, and Pivnica).

Eight of the sampled objects are dated to the $\mathrm{Ha}$ B3 period ( $9^{\text {th }}$ century BC). The loop-bow fibula with triangular foot (Fig. 5) ${ }^{125}$ and twisted torques ${ }^{126}$ from the destroyed graves in Klaonica near Travnik in central Bosnia, as well as a fragmented bow fibula, found also in the vicinity of Travnik, ${ }^{127}$ are all regional jewellery types, presumably parts of female burial attire. Both bow fibulae can be assigned to the elaborate Golinjevo type, subdivided into several variants spread throughout the territory of Dalmatia and Bosnia-Herzegovina. ${ }^{128}$ Specific to this fibulae are two, more or less marked, knobs on the bow and the big triangular foot, while typological distinctions can be made mostly on the basis of the different bow profile (round, octagonal, lenticular or flat). The ribbed bow profile, as in the case of the two sampled finds (Fig. 5), is a distinctive feature of the youngest variants from the $10^{\text {th }}$ and $9^{\text {th }}$ centuries BC. ${ }^{129}$ The dating of the fibulae to this time frame is corroborated by the grave finds from the cemetery Jablanica in northeastern Bosnia ${ }^{130}$ and from Gradac-Sokolac in the Glasinac area, ${ }^{131}$ as well as by the familiar fibula from the Otok hoard in western Herzegovina. ${ }^{132}$ Oldest among them is Grave 2 from Jablanica with a fully equipped female attire set (torques, bracelets, armlet, and pendants) dated to the late $10^{\text {th }}$ century BC, while the other mentioned finds are all typical for the final stage of the Late Bronze Age in the respective territories. Twisted torques with rhombic endings, like the sampled piece from Klaonica, are also a common jewellery type of the $\mathrm{Ha} \mathrm{B} 3$ stage for the region. ${ }^{133}$

125 Inv. no. 3 (Museum Travnik), MA-52339; Gavranović, SEJFuli 2016, Fig. $1 / 2$.

126 Inv. no. 12 (Museum Travnik, MA-152341; Gavranović, SEJFULI 2016, Fig. 1/5.

127 Inv. no. unknown (Museum Travnik), MA-52338; Gavranović, SEJFUli 2016, Fig. 5.

128 Čović 1975, 20. - Glogović 2003, 20. - Gavranović 2013, 177.

129 Čović 1975, 27.

130 Gavranović 2011, Pl.13/6.

131 Benac, Čović 1956, Pl. 46/2.

132 KÖNIg 2004, Pl. 68/3.

133 RAUnig 1982, 8. - KÖNIG 2004, 112.
One of the significant bronze types in the western Balkan is that of small socketed axes with a thickened mouth that appear in several local variations. ${ }^{134}$ The sampled objects from Grapska ${ }^{135}$ and from nearby Modriča ${ }^{136}$ both have strongly marked edges between the lateral and front sides, therefore they are best compared with axes from nearby (within a radius of $30 \mathrm{~km}$ ) depots of the $\mathrm{Ha} \mathrm{B} 3$ stage in Pašalići and in Tešanj I. ${ }^{137}$

Limited distribution in the same area can also be discerned for the small axes with a thickened, fluted mouth, such as one further sampled axe from Grapska. ${ }^{138}$ The closest analogy is an axe found in the vicinity of Tešanj, some $20 \mathrm{~km}$ to the west of Grapska. ${ }^{139}$ Socketed axes with a similar mouth shape but with an additional, wing-like ornament were cast in the settlement of Donja Dolina. ${ }^{140}$ So far, without exact parallels, is the last sampled axe from Grapska, which has vertically ribbed sides. ${ }^{141}$ For this case, measurements are a decisive method for roughly assigning them to the $9^{\text {th }}$ century BC, since axes of this size $(8.1 \mathrm{~cm})$ are not documented from Bosnia before the $\mathrm{Ha}$ B3 stage. ${ }^{142}$

Among the youngest sampled finds is the lunular razor from Grapska ${ }^{143}$ with a decorated blade (incised hatched triangles with empty zigzag space in the middle). Together with two related razors from the cemetery in Tešanj ${ }^{144}$ and one piece from the hilltop settlement Pod, ${ }^{145}$ razors of this shape are described as of the Grapska type and dated to the $9^{\text {th }}$ and $8^{\text {th }}$ centuries BC. ${ }^{146}$ Especially important for chronological determination is the razor from the long-occupied settlement of Pod; it was found in the layer from the $9^{\text {th }}$ century BC. ${ }^{147}$ In Grave 1 from Tešanj the razor was part of a male warrior equipment including a short sword and a socketed axe, both with incised decoration, very similar to

134 WanZeK 1989, 199. - ŽEeravica 1993, 75. - KöNIG 2004, 132. GAVRANOvić, JAŠAREVIĆ 2016, Map 5.

135 Inv. no. 1736 (Museum Doboj), MA-153346; ŽEravica 1993, Pl. 21/272. - KöNIg 2004, Pl. 77/7.

136 Inv. no. 4440 (Museum Doboj), MA-152357; Gavranović, JAŠAREVIĆ 2016, Fig. 6.

137 KöNIg 2004, Pl. 59B/3; 61B/4.

138 Inv. no. 1735 (Museum Doboj), MA-152342; ŽEravica 1993,

Pl. 21/271. - KÖNIG 2004, Pl. 77/8.

139 Truhelka 1907, 75. - Žeravica 1993, Pl. 21/273.

140 ŽEravica 1993, Pl. 37/504.

141 Inv. no. 1734 (Museum Doboj), MA-152347; ŽEravica 1993,

Pl. 37/490. - KÖNIG 2004, Pl. 77/6.

142 Žeravica 1993, Pl. 21

143 Inv. no. 1747 (Museum Doboj), MA-152349; BenAC 1954, 167. -

Weber 1996, Pl. 54/1.

144 Truhelka 1907, 58.

145 Čović 1983, Pl. 56/5

146 Jockenhövel 1971, 214. - Weber 1996, 249.

147 Čović 1983, 434. - Gavranović 2011, 257. 


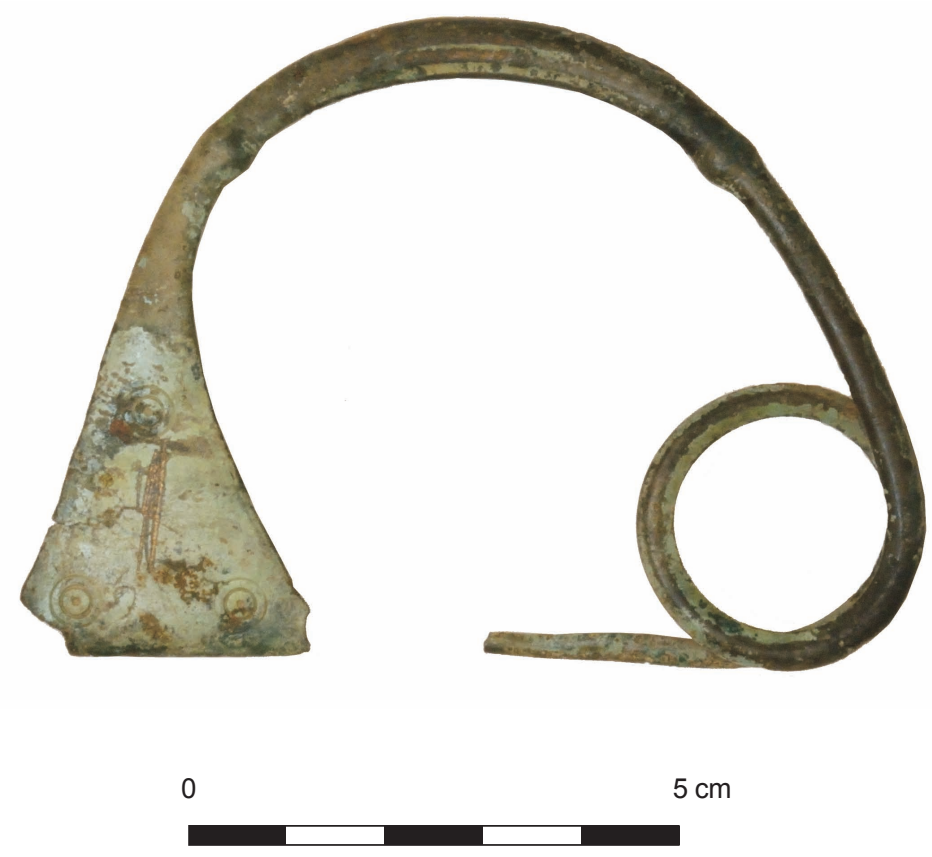

Fig. 5. Sampled bow fibula from Klaonica (Inv. no. 3, Museum Travnik, MA - 152339) (Photo: M. Gavranović, M. Mehofer).

the sampled razor from Grapska. ${ }^{148}$ The same geometrical ornamentation is typical for a number of the local bronze finds from this period, including a prominent bronze scabbard from Veliki Mošunj in central Bosnia and oversized round belt buckles from the depots Ometala and Krehin Gradac in Herzegovina. ${ }^{149}$ The incised decorations with the same motifs (hatched triangles, lunular motifs, and zigzag lines) are also characteristic for the ceramics from this period, which are especially well documented in the layers of the previously mentioned settlement of Pod. ${ }^{150}$

\section{Archaeometallurgical Analyses (M. Gavranović,} M. Mehofer)

The archaeometallurgical investigation aims to generate a broad dataset of artefacts from Bosnia-Herzegovina dating to the Late Bronze Age. Although objects dating to the Chalcolithic and Early Bronze Age from the region under study ${ }^{151}$ and neighbouring territories ${ }^{152}$ have already been examined, a comprehensive series of analyses on Late Bronze Age metal artefacts, as known from e.g. Slovenia, Italy or

148 Harding 1995, 59. - Ž́Eravica 1993, Pl. 37/502.

149 KÖNIG 2004, Pl. 63/2; 67/5;

150 Čović 1983, 422. - Gavranović 2011, Fig. 254.

151 Čović 1995, 105-107 and Tabs. 1-3.

152 Begemann, SchmitT-Stecker 2005.
Bulgaria, ${ }^{153}$ are still missing. By generating a 'geochemical fingerprint ${ }^{\prime}{ }^{154}$ of the studied metals and ores, and with the help of the above-mentioned database, the project aims to investigate a possible connection between local workshops and copper ore deposits from the region. The main emphasis of this research is on the question whether the increase of metal artefacts detectable within the archaeological record derived directly from the use of local copper ore resources - as they were accessible at this time period - or, if a longrange, European distribution network ${ }^{155}$ was used to cover the need for raw materials. Furthermore, it should be examined if locally distributed bronze objects can be distinguished from supra-regional through not only typological differences but also by analysis of metal composition. With metal analyses it should be investigated if this typological and geographically clustered diversity also has a technological, metallurgical background. This would eventually allow for conclusions on different distribution networks.

153 Junghans, SAngmeister, Schröder 1968a, c. - Stos-Gale Gale, Houghton, Speakman 1995. - Trampuž-Orel 1996. Trampuž-Orel 1999. - Pernicka et al. 1997. - Hook 2007. - Giumlia-Mair 2009. - Jung, Mehofer, Pernicka 2011. - Mehofer 2011. - Jung, Mehofer 2013a. - Jung, Mehofer 2013b. - See PerNICKA et al. 2016 (this volume).

154 Pernicka 1999. - Pernicka 2014.

155 Sperber 2004. 


\subsection{Methods, Sampling Techniques}

First, M. Mehofer conducted analyses of major and minor elements at the VIAS laboratory with a scanning electron microscope (SEM-EDS, Zeiss EVO 60 XVP). These investigations permitted an overview of the chemical composition of the sampled objects and, at the same time, provided the basis for a selection of samples intended for trace and lead isotope analysis. ${ }^{156}$ A precondition for the applicability of the here presented methods for the determination of the origin of the metals is that the chemical composition as well as the lead isotope composition ${ }^{157}$ of the studied metal has not been changed by manufacture processes, e.g. alloying, recycling, melting together with other metals or the addition of lead.

In the first step, 30 samples, characterised by a low lead concentration at or below 1 mass\% by the SEM analyses, were selected. These samples were subsequently subjected to a trace element analysis at the Curt-Engelhorn Centre for Archaeometry in Mannheim under the direction of E. Pernicka (see Tab. 2). In general, it is assumed that such low lead concentrations derive from the smelted copper ore ${ }^{158}$ and were not alloyed on purpose. It is important to mention at this point that within the 76 sampled artefacts, examples with higher lead concentrations than 1 mass \% have also been found. They were not chosen for the first series of analyses as it is not possible to decide in advance whether the increased concentration of lead can be explained by alloying or whether it entered the copper as an impurity from the used copper ore.

\subsection{Discussion of the Analytical Results}

The following discussion is based on the outcome of the first analyses on 29 artefacts. The analysis results of object Inv. no. 21 from Klaonica are not included because they are influenced by effects of corrosion (Tab. 2, MA-152340). The analyses show that the sampled items are made of tin bronze with a varying tin concentration between $1.57-12.4 \%$. The lead concentration is, with the exception of three objects, ${ }^{159}$ always below 1 mass\% (Tab. 2).

For further discussion, the artefacts were divided according to the age determination in order to be able to describe possible tendencies within the metal supply during the different time periods. By way of qualification, it

156 Lutz, Pernicka 1996. - Niederschlag et al. 2003. - Pernicka 2014, 250-259, 253, Tab. 11.1.

157 Pernicka 2014, 255.

158 Pernicka 1987, 700. - Jung, Mehofer 2013a, 184.

159 Inv. no. 1739 (socketed axe, Grapska, MA-152344), Inv. no. 2749 (socketed axe, Brezovo Polje, MA-152328) and a bow fibula from Travnik (without Inv. no., MA-152338). should, however, be stated that for each group only a relatively small amount of analyses are on hand at this point. For the periods $\mathrm{Ha} \mathrm{A} 1$ and $\mathrm{Ha} \mathrm{A} 2-\mathrm{B} 1$, only 9 analytical results each can be used; for period $\mathrm{Ha} \mathrm{B} 1$ only three analyses are available; and for period $\mathrm{Ha}$ B3 we have 8 samples (Tab. 2). For this reason the here presented conclusions can only be considered as preliminary.

\subsection{Tin Concentration}

The first step included the evaluation of the tin concentrations in the objects, as well as a determination of their mean and median values. It is possible to see that the items belonging to group $\mathrm{Ha}$ A2-B1 have, with $10.1 \%$, the highest mean value of tin of all investigated artefacts (Tab. 1). The median value of this group is approximately $11.3 \%$, while the results of the older and younger dated groups vary between $6.0 \%$ and $7.4 \%$. The artefacts of group $\mathrm{Ha}$ B1 have the lowest values, although the validity of these results is limited due to the small amount of investigated objects. Generally, one can observe that the average concentration of tin increases from period $\mathrm{Ha}$ A1 towards $\mathrm{Ha}$ A2-B1, whereas from phase Ha B1 toward HA B3 it declines again (Tab. 1).

Considering this outcome, there is the impression that, especially during the periods $\mathrm{Ha} \mathrm{A} 1$ and $\mathrm{Ha} \mathrm{A} 2-\mathrm{B} 1$, a relatively good supply of tin or tin ore for bronze production existed. A detailed view of the results of the individual objects, however, displays that the contents of tin within each of the chronological groups differ significantly. A socketed axe from Kućišta (Ha A1), for example, shows only $4.5 \%$ $\mathrm{Sn},{ }^{160}$ while another one from the hoard Grapska ${ }^{161}$ (Ha B1) has an even lower tin concentration of only $1.57 \%$. A socketed axe from Modriča ${ }^{162}$ (Ha B3) also has a very low tin concentration with a value of $3.2 \% \mathrm{Sn}$. These concentrations are too low to have a significant influence on the hardness ${ }^{163}$ of the metal. A considerable increase in hardness ${ }^{164}$ could have been achieved only through intensive cold working. It is possible that re-melted bronze, with a decreased concentration of tin due to the repeated addition of copper, was used to produce these artefacts.

The highest concentrations of tin (up to $12.4 \% \mathrm{Sn}$ ) can be observed within the group $\mathrm{Ha}$ A2-B1. The group consists of artefacts originating from the Brezovo Polje hoard. The varying age determinations (Early to Younger Urnfield

160 Inv. no. 1794, MA-152351.

161 Inv. no. 1738, MA-152343. - At the same time the socketed axe from Derventa (Inv. no. 4605, MA-152356), dating to the same period, holds a concentration of $12.4 \%$ tin.

162 Inv. no. 4440, MA-152357.

163 Northover i989, 114 and Fig. 13.5. - Wang, OTtaway 2004. 164 Northover 1989, 114 and Fig. 13.5. 
Tab. 1. The table presents the mean and median values for the tin and lead concentrations of the artefacts under study. All values are given in mass percent.

\begin{tabular}{|l|c|c|c|c|}
\hline Period & Sn $(\%)$ & Sn $(\%)$ & $\mathrm{Pb}(\%)$ & $\mathrm{Pb}(\%)$ \\
\hline Ha A1 $(\mathrm{n}=9)$ & mean value & median value & mean value & median value \\
\hline Ha A2-Ha B1 (n=9) & 7.3 & 7.4 & 0.28 & 0.25 \\
\hline Ha B1 $(\mathrm{n}=3)$ & 10.1 & 11.3 & 0.45 & 0.25 \\
\hline Ha B3 $(\mathrm{n}=8)$ & 6.6 & 6.0 & 0.59 & 0.34 \\
\hline
\end{tabular}

period) of the individual socketed axes correlates well with the observable varying minor element and trace element concentrations, which for their part also suggests different places or times of production. Even typologically similar classified objects from this hoard - e.g. the socketed axes with V-Rips ${ }^{165}$ - show differences, as their tin concentrations vary between $5.7 \%$ and $12.4 \%$. Of particular note is the fact that almost all analysed socketed axes from Brezovo Polje have high tin concentrations exceeding $10 \%$ (Tab. 2) which is comparable with a socketed axe from Derventa (Tab. 2, Inv. no. 4605). Although trace element concentrations distinguish them easily from one another, three axes from Brezovo Polje (Inv. no. 2742, 2747, 2750) have a common typological feature with the axe from Derventa - they are all decorated with variations of Y-Ribs, a distinctive ornamentation of socketed axes between $\mathrm{Ha} \mathrm{A} 2$ and $\mathrm{Ha}$ B1.

The widest differences in tin concentrations (1.57$12.4 \% \mathrm{Sn}$ ) are observable within the $\mathrm{Ha} \mathrm{B} 1$ group. The metal objects dated to the latest period ( $\mathrm{Ha} \mathrm{B} 3)$ show a regular tin concentration below $10 \%$, nevertheless one socketed axe from Grapska ${ }^{166}$ still has a tin concentration of $9.8 \%$.

Subsequently, these results were combined with the outcome of the analyses conducted by N. Trampuž-Orel on objects from Slovenia. The emphasis of this investigation was placed on the results of the analyses of finished products since the ingots partly show a very high concentration of lead - up to 50.2 mass $\%,{ }^{167}$ and were not alloyed with tin, which is why they are not directly comparable with the finished products and therefore had to be excluded. The results of the investigation of bronzes from the Slovenian hoards of Čermožiše (Ha A1), Kanalski Vrh I (Ha B1) and Šempeter $(\mathrm{Ha} \mathrm{B} 1)^{168}$ show a similar variability in the concentration of tin, fluctuating between $0 \%$ and $20 \%$. The average tin con-

165 See Chapter 2.2 Ha A2/Ha B1-Group.

166 Inv. no. 1735, MA-152342.

167 Trampuž-Orel 1996, 227-229.

168 Trampuž-Orel 1996, 213-214, 225-227, 233. centration of the artefacts found in the hoard from Šempeter is, e.g. at $4.04 \% .{ }^{169}$ A. Giumlia-Mair describes a similar phenomenon for the bronze artefacts found in northeastern Italy, ${ }^{170}$ which are dated to the Final Bronze Age.

\subsection{Trace Element Analyses}

The evaluation of the trace element concentrations revealed further noteworthy insights into metal consumption during the Late Bronze Age. Within the items analysed until now, no objects with a significantly higher antimony or arsenic concentration could be found, so that fahlore can be largely excluded as a primary ore. The copper was probably sourced primarily from the mining regions, which largely mined and smelted chalcopyritic ores.

While the earlier artefacts of the groups $\mathrm{Ha} \mathrm{A} 1$ and Ha A2-B1 show a relatively broad variance, the objects of groups $\mathrm{Ha}$ B1 and $\mathrm{Ha}$ B3 seem to have a narrower variance $^{171}$ between their trace element concentrations (Fig. 6). These groups also contain artefacts with differing typology and function, including socketed axes, fibulae, razors, and torques.

Although it is far too early to draw conclusive results on the provenance of artefacts or the copper used, some interesting observations can be pointed out, regarding the possible foreign origin of some artefacts. As an example, we can mention two typologically almost identical socketed axes of stage Ha B1 from Grapska (Tab. 2, Inv. nos. 1738-1739). Somewhat unexpected is, however, their disparity in tin concentration. Generally speaking, this is a very atypical axe form for the area under study with nearest analogies occurring in Transylvania and northern Hungary. One could only speculate if the technological variance is somehow connected to the different region of origin, or if one or both

169 Trampuž-Orel 1996, 233.

170 Giumlia-Mair 2009, 152 and Fig. 2.

171 The trace element patterns of the finds within group $\mathrm{Ha}$ B1 seem to follow the same model, nevertheless the amount of data, which is based on three analysis results only, is too small to allow further interpretations. 

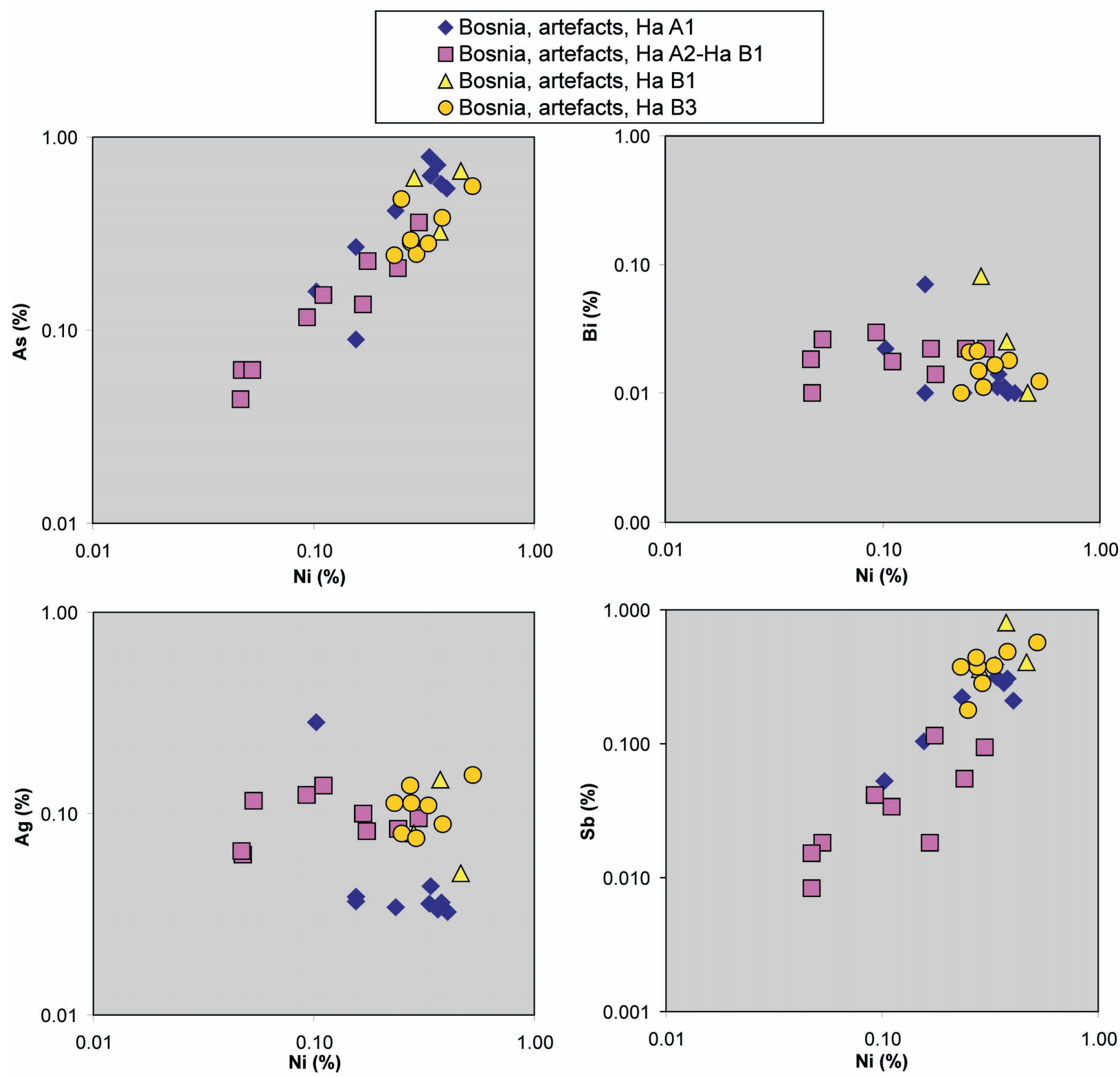

Fig. 6. Concentration of arsenic, silver, nickel, antimony and bismuth in the archaeological artefacts analysed. Note that the results of the finds dating to the stage $\mathrm{Ha} \mathrm{B} 3$ form a relatively closed group in all diagrams (Graphics: M. Mehofer).

axes were locally produced. However, without supplementary analysis it is hard to provide any kind of reasonable explanation for now.

Additionally, the trace element concentrations were again compared with the ones from the hoards from Čermožiše, Kanalski Vrh I, and Šempeter in Slovenia. The trace element concentrations of the artefacts coming from these hoards have a wider variation range than the objects from Bosnia, with partly remarkable differences. For instance, the concentrations of silver ${ }^{172}$ of the finished products com-

172 Trampuž-Orel 1996, 213-214, 225-227, 233. ing from Čermožiše (Ha A1) and Kanalski Vrh I (Ha A1) are so low that they were actually beneath the detection limit of the used measuring device (Fig. 7). Only the metal artefacts from Šempeter (Ha B1) show a similar concentration of silver. These observable differences in the concentrations of antimony and especially silver ${ }^{173}$ between the Slovenian

173 Observing the relatively low silver concentrations of the bronze items dating to the $\mathrm{Ha}$ A1 period from Bosnia-Herzegovina, it would be enticing, of course, to assume similar copper sources for them and the Slovenian hoards - nevertheless this would be a bit of a stretch at this point of research. 

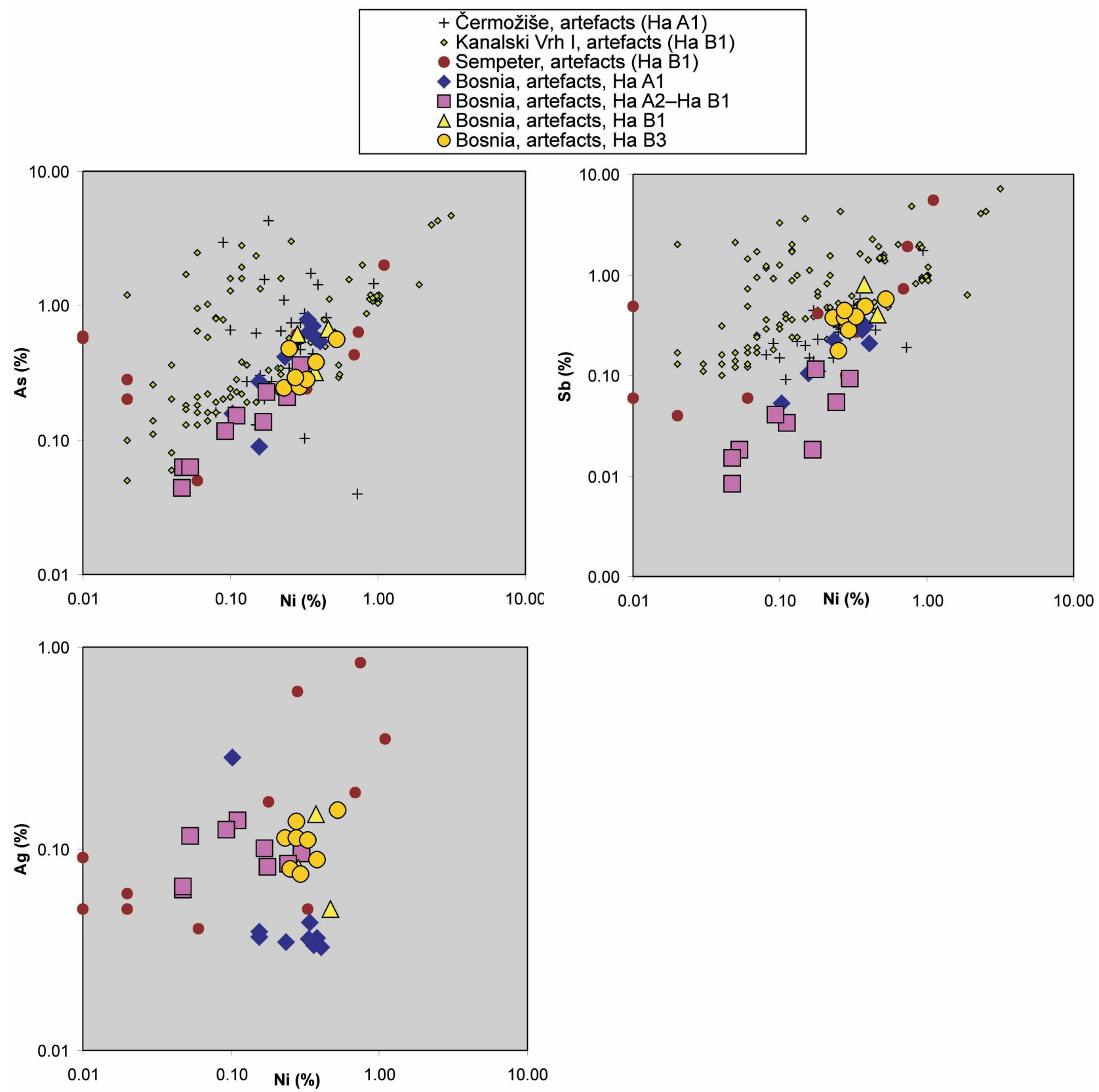

Fig. 7. Concentration of arsenic, silver, nickel and antimony in the analysed objects and in artefacts from Slovenian hoards. It is worth pointing out that in the data set of the Slovenian artefacts the silver and bismuth concentrations were below the detection limit of the used measuring device (Trampuž-Orel 1996, 213-233) (Graphics: M. Mehofer).

and Bosnian artefacts allow for the hypothesis that their producers were taking part in different metal exchange networks.

\section{Conclusions (M. Gavranović, M. Mehofer)}

The analyses conducted for the first time on artefacts from Bosnia-Herzegovina provide a first assessment of metal supply during the Late Bronze Age. With regard to trace element analysis and tin concentration, a few preliminary statements can be made as well. The evaluation of the average tin concentrations shows that the tin supply seems to be sufficient during the stages $\mathrm{Ha} 1$ and $\mathrm{Ha} \mathrm{A} 2 / \mathrm{Ha}$ B1, whereas in the following period the tin amount decreased. This generally falls into line with the already stated observations that 
Tab. 2. Chemical compositions of the analysed artefacts (ED-XRF). All values are given in mass percent. In all samples Zn and Se were below the detection limit of $0.01 \%$ and $\mathrm{Cd}$ and Te were below $0.005 \%$.

\begin{tabular}{|c|c|c|c|c|c|c|c|c|c|c|c|c|c|c|}
\hline $\begin{array}{l}\text { Inv. } \\
\text { no. }\end{array}$ & Artefact & Site & Date & Lab. no. & $\mathrm{Cu}$ & Sn & $\mathrm{Pb}$ & As & $\mathrm{Sb}$ & Ag & $\mathrm{Ni}$ & $\mathrm{Fe}$ & Co & $\mathrm{Bi}$ \\
\hline 1737 & socketed axe & Grapska & $\mathrm{Ha}$ A1 & $\begin{array}{l}\text { MA- } \\
152345\end{array}$ & 90 & 8.0 & 0.32 & 0.63 & 0.31 & 0.043 & 0.34 & $<0.05$ & 0.03 & 0.01 \\
\hline 1743 & sickle & Grapska & $\mathrm{Ha}$ A1 & $\begin{array}{l}\text { MA- } \\
152348\end{array}$ & 92 & 7.4 & 0.15 & 0.27 & 0.105 & 0.039 & 0.16 & 0.05 & 0.06 & 0.07 \\
\hline 1793 & socketed axe & Kućišta & Ha A1 & $\begin{array}{l}\text { MA- } \\
152351\end{array}$ & 92 & 7.2 & 0.09 & 0.09 & 0.105 & 0.036 & 0.16 & 0.11 & 0.02 & $<0.01$ \\
\hline 1794 & socketed axe & Kućišta & $\mathrm{Ha}$ A1 & $\begin{array}{l}\text { MA- } \\
152352 \\
\end{array}$ & 94 & 4.5 & 0.56 & 0.42 & 0.22 & 0.034 & 0.24 & 0.13 & 0.03 & $<0.01$ \\
\hline 1798 & chisel & Kućišta & $\mathrm{Ha}$ A1 & $\begin{array}{l}\text { MA- } \\
152350\end{array}$ & 93 & 4.9 & 0.34 & 0.71 & 0.28 & 0.033 & 0.36 & 0.09 & 0.10 & 0.01 \\
\hline 1804 & spearhead & Kućišta & $\mathrm{Ha}$ A1 & $\begin{array}{l}\text { MA- } \\
152353\end{array}$ & 91 & 7.8 & 0.25 & 0.57 & 0.31 & 0.036 & 0.38 & $<0.05$ & 0.02 & $<0.01$ \\
\hline 2752 & sickle & $\begin{array}{l}\text { Brezovo } \\
\text { Polje }\end{array}$ & Ha A1 & $\begin{array}{l}\text { MA- } \\
152336\end{array}$ & 90 & 9.4 & 0.12 & 0.16 & 0.053 & 0.284 & 0.10 & $<0.05$ & 0.02 & 0.02 \\
\hline 5350 & sword & $\begin{array}{l}\text { Majdan/ } \\
\text { Ridžali }\end{array}$ & $\mathrm{Ha}$ A1 & $\begin{array}{l}\text { MA- } \\
152354 \\
\end{array}$ & 92 & 6.2 & 0.49 & 0.79 & 0.39 & 0.036 & 0.34 & $<0.05$ & 0.02 & 0.01 \\
\hline 5354 & spearhead & $\begin{array}{l}\text { Majdan/ } \\
\text { Ridžali }\end{array}$ & Ha A1 & $\begin{array}{l}\text { MA- } \\
152355\end{array}$ & 88 & 10.2 & 0.17 & 0.54 & 0.21 & 0.030 & 0.40 & 0.06 & 0.04 & $<0.01$ \\
\hline 2737 & socketed axe & $\begin{array}{l}\text { Brezovo } \\
\text { Polje }\end{array}$ & $\begin{array}{l}\mathrm{Ha} \text { A2- } \\
\mathrm{Ha} \mathrm{B1}\end{array}$ & $\begin{array}{l}\text { MA- } \\
152333\end{array}$ & 88 & 11.5 & 0.06 & 0.04 & 0.015 & 0.065 & 0.05 & $<0.05$ & $<0.01$ & 0.02 \\
\hline 2741 & socketed axe & $\begin{array}{l}\text { Brezovo } \\
\text { Polje }\end{array}$ & $\begin{array}{l}\mathrm{Ha} \text { A2- } \\
\mathrm{Ha} \text { B1 }\end{array}$ & $\begin{array}{l}\text { MA- } \\
152332 \\
\end{array}$ & 88 & 10.8 & 0.70 & 0.21 & 0.054 & 0.084 & 0.24 & $<0.05$ & 0.02 & 0.02 \\
\hline 2742 & socketed axe & $\begin{array}{l}\text { Brezovo } \\
\text { Polje }\end{array}$ & $\begin{array}{l}\mathrm{Ha} \text { A2- } \\
\mathrm{Ha} \mathrm{B1}\end{array}$ & $\begin{array}{l}\text { MA- } \\
152329 \\
\end{array}$ & 87 & 12.4 & 0.13 & 0.06 & 0.008 & 0.063 & 0.05 & $<0.05$ & $<0.01$ & $<0.01$ \\
\hline 2744 & socketed axe & $\begin{array}{l}\text { Brezovo } \\
\text { Polje }\end{array}$ & $\begin{array}{l}\mathrm{Ha} \text { A2- } \\
\mathrm{Ha} \text { B1 }\end{array}$ & $\begin{array}{l}\text { MA- } \\
152334 \\
\end{array}$ & 93 & 5.7 & 0.41 & 0.23 & 0.114 & 0.082 & 0.18 & 0.05 & 0.02 & 0.01 \\
\hline 2747 & socketed axe & $\begin{array}{l}\text { Brezovo } \\
\text { Polje }\end{array}$ & $\begin{array}{l}\mathrm{Ha} \mathrm{A2-} \\
\mathrm{Ha} \mathrm{B1}\end{array}$ & $\begin{array}{l}\text { MA- } \\
152330\end{array}$ & 87 & 12.0 & 0.18 & 0.36 & 0.094 & 0.094 & 0.30 & 0.15 & 0.05 & 0.02 \\
\hline 2749 & socketed axe & $\begin{array}{l}\text { Brezovo } \\
\text { Polje }\end{array}$ & $\begin{array}{l}\mathrm{Ha} \text { A2- } \\
\mathrm{Ha} \mathrm{B1}\end{array}$ & $\begin{array}{l}\text { MA- } \\
152328 \\
\end{array}$ & 90 & 8.0 & 1.28 & 0.14 & 0.018 & 0.100 & 0.17 & $<0.05$ & 0.02 & 0.02 \\
\hline 2750 & socketed axe & $\begin{array}{l}\text { Brezovo } \\
\text { Polje }\end{array}$ & $\begin{array}{l}\mathrm{Ha} \mathrm{A2-} \\
\mathrm{Ha} \text { B1 }\end{array}$ & $\begin{array}{l}\text { MA- } \\
152331 \\
\end{array}$ & 86 & 12.4 & 0.25 & 0.15 & 0.034 & 0.138 & 0.11 & 0.63 & 0.05 & 0.02 \\
\hline 2751 & socketed axe & $\begin{array}{l}\text { Brezovo } \\
\text { Polje }\end{array}$ & $\begin{array}{l}\mathrm{Ha} \text { A2- } \\
\mathrm{Ha} \text { B1 }\end{array}$ & $\begin{array}{l}\text { MA- } \\
152335 \\
\end{array}$ & 88 & 11.3 & 0.23 & 0.06 & 0.018 & 0.116 & 0.05 & 0.18 & 0.02 & 0.03 \\
\hline 2754 & spearhead & $\begin{array}{l}\text { Brezovo } \\
\text { Polje }\end{array}$ & $\begin{array}{l}\mathrm{Ha} \text { A2- } \\
\mathrm{Ha} \mathrm{B1}\end{array}$ & $\begin{array}{l}\text { MA- } \\
152337\end{array}$ & 92 & 6.9 & 0.81 & 0.12 & 0.041 & 0.124 & 0.09 & $<0.05$ & 0.02 & 0.03 \\
\hline 1738 & socketed axe & Grapska & Ha B1 & $\begin{array}{l}\text { MA- } \\
152343\end{array}$ & 96 & 1.57 & 0.34 & 0.61 & 0.36 & 0.080 & 0.29 & 0.11 & 0.18 & 0.08 \\
\hline 1739 & socketed axe & Grapska & Ha B1 & $\begin{array}{l}\text { MA- } \\
152344 \\
\end{array}$ & 91 & 6.0 & 1.41 & 0.32 & 0.80 & 0.148 & 0.37 & $<0.05$ & 0.06 & 0.02 \\
\hline 4605 & socketed axe & $\begin{array}{l}\text { Kula. } \\
\text { Derventa }\end{array}$ & Ha B1 & $\begin{array}{l}\text { MA- } \\
152356\end{array}$ & 86 & 12.4 & 0.01 & 0.67 & 0.40 & 0.050 & 0.47 & 0.12 & 0.03 & $<0.01$ \\
\hline
\end{tabular}


Tab. 2. continued.

\begin{tabular}{|c|c|c|c|c|c|c|c|c|c|c|c|c|c|c|}
\hline $\begin{array}{l}\text { Inv. } \\
\text { no. }\end{array}$ & Artefact & Site & Date & Lab. no. & $\mathrm{Cu}$ & Sn & $\mathrm{Pb}$ & As & $\mathrm{Sb}$ & $\mathrm{Ag}$ & $\mathrm{Ni}$ & $\mathrm{Fe}$ & Co & $\mathrm{Bi}$ \\
\hline 3 & bow fibula & $\begin{array}{l}\text { Klaonica. } \\
\text { Travnik }\end{array}$ & $\mathrm{Ha} \mathrm{B3}$ & $\begin{array}{l}\text { MA- } \\
152339\end{array}$ & 88 & 8.2 & 1.99 & 0.48 & 0.177 & 0.080 & 0.25 & 0.21 & 0.16 & 0.02 \\
\hline $21 \%$ & belt buckle & $\begin{array}{l}\text { Klaonica. } \\
\text { Travnik }\end{array}$ & Ha B3 & $\begin{array}{l}\text { MA- } \\
152340\end{array}$ & 74 & 20.7 & 2.22 & 1.01 & 0.88 & 0.243 & 0.21 & 0.77 & $<0.01$ & 0.05 \\
\hline 1734 & socketed axe & Grapska & $\mathrm{Ha} \mathrm{B3}$ & $\begin{array}{l}\text { MA- } \\
152347\end{array}$ & 91 & 7.5 & 0.19 & 0.24 & 0.37 & 0.113 & 0.23 & 0.31 & 0.06 & $<0.01$ \\
\hline 1735 & socketed axe & Grapska & Ha B3 & $\begin{array}{l}\text { MA- } \\
152342\end{array}$ & 89 & 9.8 & 0.43 & 0.25 & 0.28 & 0.075 & 0.29 & 0.05 & 0.05 & 0.01 \\
\hline 1736 & socketed axe & Grapska & Ha B3 & $\begin{array}{l}\text { MA- } \\
152346\end{array}$ & 91 & 7.0 & 0.52 & 0.38 & 0.49 & 0.088 & 0.38 & $<0.05$ & 0.11 & 0.02 \\
\hline 1747 & razor & Grapska & $\mathrm{Ha} \mathrm{B} 3$ & $\begin{array}{l}\text { MA- } \\
152349\end{array}$ & 92 & 5.8 & 0.75 & 0.28 & 0.38 & 0.110 & 0.33 & $<0.05$ & 0.06 & 0.02 \\
\hline 4440 & socketed axe & Modriča & $\mathrm{Ha} \mathrm{B} 3$ & $\begin{array}{l}\text { MA- } \\
152357\end{array}$ & 95 & 3.2 & 0.30 & 0.29 & 0.44 & 0.137 & 0.27 & 0.08 & 0.07 & 0.02 \\
\hline / & neck ring & $\begin{array}{l}\text { Klaonica. } \\
\text { Travnik }\end{array}$ & $\mathrm{Ha} \mathrm{B} 3$ & $\begin{array}{l}\text { MA- } \\
152341\end{array}$ & 91 & 6.4 & 0.49 & 0.56 & 0.573 & 0.156 & 0.53 & $<0.05$ & 0.039 & 0.012 \\
\hline / & bow fibula & Travnik & $\mathrm{Ha}$ B3 & $\begin{array}{l}\text { MA- } \\
152338\end{array}$ & 91 & 6.1 & 1.23 & 0.29 & 0.38 & 0.113 & 0.28 & 0.05 & 0.05 & 0.01 \\
\hline
\end{tabular}

** The results of this artefact are influenced by corrosion processes; therefore they are not included in the text.

with the beginning of the $9^{\text {th }}$ century BC a general shortage of $\operatorname{tin}^{174}$ can be identified.

It is also worth pointing out that, in terms of chemical composition all eight objects dated to $\mathrm{Ha}$ B3 form a close group in the trace element diagrams (Fig. 6). Despite the fact that these eight objects represent functionally and typologically very different items (axes, razors, and jewellery) and come from different sites, the technological aspect behind their production seems to be somehow comparable. The common characteristic of all eight bronze objects is their regional, restricted distribution within the western Balkans. Further analysis (lead isotope analyses) and an expansion of the dataset will certainly reveal whether the chemical resemblance of the eight regional bronze forms of the $9^{\text {th }}$ century $\mathrm{BC}$ is just a coincidence or indeed a product of a similar archaeometallurgical background.

Observing the trace element concentrations of all four groups, it could be determined that, due to the low antimony concentrations, chalcopyritic ore was probably used for the manufacturing of the copper. To date, the question remains: from which mining regions was the used copper obtained? In order to enhance the knowledge about the extent of exchange and metal trade, the geological samples from the collection of the Travnik museum were sampled as well.

174 Trampuž-Orel 1996, 233. - Sperber 2004, 335.
On the one hand, various fahlores, ${ }^{175}$ and on the other hand, chalcopyritic ores were already analysed with SEM-EDS. In the next step, the focus will be placed upon the geochemical characterisation of these ore samples. As a consequence, specific mining regions can be confirmed or eliminated as possible regions of production for the copper used.

Thus, it is to conclude that the next stage of this research project will include not only the localisation of the mining regions from which the used copper came from, but also the enactment of further comparative analyses of copper ores and metals objects from Bosnia-Herzegovina and neighbouring regions. ${ }^{176}$ Only then we will be able to gain a more comprehensive insight into the hitherto almost unknown Late Bronze Age metallurgical processes in this part of the European continent.

175 As mentioned before, e.g. in the region of the village of Mračaj also modern mines on these ores can be found. - KATZER 1905, 374. - Čović 1995, 108, 109 and Tab. 4.

176 This e.g. comprises the famous mines of Bor, Rudna Glava, and Majdanpek in eastern Serbia as well as artefacts found in the neighbouring regions. - Junghans, SAngmeister, Schröder 1968a, b, c. - Pernicka et al. 1993, 38-50 and Tabs. 8-9.-Begemann, Pernicka, Schmitt-Strecker 1995, 145 and Fig. 1b. - Trampuž-Orel 1996. Pernicka et al. 1997. - Begemann, Schmitt-Stecker 2005. - See also E. Pernicka et al. 2016 (this volume). 


\section{Acknowledgements}

The idea for the project had been drafted in 2012, when Mario Gavranović was giving an invited lecture at the Vienna Institute for Archaeological Science, University of Vienna. The investigations are carried out within, and gratefully financed by, an ongoing fruitful cooperation between the Institute for Oriental and European Archaeology (OREA), Austrian Academy of Sciences, and the Vienna Institute for Archaeological Science (VIAS), University Vienna. Due to their support, sincere thanks are given to OREA director Barbara Horejs und VIAS director Timothy Taylor.

\section{References}

Balen-Letunić

D. BALEN-Letunić, Nekoliko ostava iz kasnog brončanog doba na području Srijema, Vijesnik Arheološkog muzeja u Zagrebu 21, 1988, 5-21.

BASLER 1999

Đ. BASLER, Rudnici i metalurški pogoni rimskog doba u Bosni i Hercegovini (s osobitim osvrtom na pogone u dolini rijeke Japre). In: Radovi sa simpozijuma rudarstvo i metalurgija Bosne i Hercegovine od prahistorije do početka XX vijeka u Zenici 1973. Zenica 1999, 89-118.

Begemann, Pernicka, Schmitt-Strecker 1995

F. Begemann, E. Pernicka, S. Schmitt-Strecker, Searching for the ore sources of Eneolithic and Early Bronze Age copper artefacts from Serbia. In: P. Petrović, S. ĐurĐekanović (Eds.), Ancient Mining and Metallurgy in Southeast Europe. Archaeological Institute, Museum of Mining and Metallurgy, Belgrade - Bor 1995, 143-149.

Begemann, Schmitt-STEcker 2005

F. Begemann, S. SchmitT-STrecker, Kupfer- und bronzezeitliche Artefakte vom Westbalkan: Zur Frage nach den Quellen ihres Kupfers, Prähistorische Zeitschrift 80, 2005, 49-65.

BELIĆ 2010

B. Belić, Topolovaca Bregovi kod Odžaka / Topolovaca Bregovi near Odžak, Glasnik Zemaljskog muzeja u Sarajevu 52, 2010, 225-229.

BENAC 1967

A. Benac, Kameni kalupi sa Pivnice, Glasnik Zemaljskog muzeja u Sarajevu 17, 1967, 21-40.

BENAC, Čović 1956

A. Benac, B. Čović, Glasinac: Teil I Bronzezeit. Katalog der vorgeschichtlichen Sammlung des Landesmuseums in Sarajevo 1, Sarajevo 1956.

BLEČIĆ-KAVUR, JAŠAREVIĆ 2013

M. BleČić-Kavur, A. JašAREvić, Kasnobrončanodobna ostava Majdan/Ridžali, Godišnjak Centra za balkanološka ispitivanja 43, 2013, 35-49

BojanOvsKi 1999

I. Bojanovski, Antičko rudarstvo u Bosni i Hercegovini u svjetlu epigrafskih i numizmatickih izvora. In: Radovi sa simpozijuma rudarstvo i metalurgija Bosne i Hercegovine od prahistorije do početka XX vijeka u Zenici 1973, Zenica 1999, 133-175.

BORIĆ 1997

D. Borić, Ostava kasnog bronzanog doba iz Futoga, Rad muzeja Vojvodine 39, 1997, 41-93.

Clausing 2003

C. Clausing, Ein urnenfelderzeitlicher Hortfund von Slavonski Brod, Kroatien, Jahrbuch des Römisch-Germanischen Zentralmuseums Mainz 50/1, 2003, 47-205.
ČERČE, ŠINKOVEC 1995

P. ČERČE, I. ŠINKOvEC, Katalog depojev pozne bronaste dobe / Catalogue of Hoards of the Urnfied Culture. In: B. TERŽAN (Ed.), Depojske in posamezne kovinske najdbe bakrene in bronaste dobe na Slovenskem I / Hoards and Individual Metal finds from the Eneolithic and Bronze Ages in Slovenia I. Catalogi et Monographiae 29, Ljubljana 1995, 129-333.

ĆurČIĆ 1902

V. Ćurčić, Gradina an der Ramaquelle im Bezirke Prozor, Wissenschaftliche Mitteilungen aus Bosnien und Herzegowina 8, 1902, 48-61.

ĆURČIĆ 1908

V. ĆURČIĆ, Prilozi poznavanju prethistorijskog rudarstva i talioničarstva brončanog doba u Bosni i Hercegovini, Glasnik Zemaljskog Muzeja Bosne i Hercegovine 20, 1908, 77-90.

Čović 1975

B. Čović, Zwei spezifische Typen der westbalkanischen Bogenfibel, Wissenschaftliche Mitteilungen des Bosnisch-Herzegowinischen Landesmuseums 5, 1975, 19-33.

Čović 1983

B. Čović, Srednjobosanska grupa. In: A. Benac (Ed.), Praistorija Jugoslovenskih Zemalja IV: Bronzano doba. Sarajevo 1983, 433-461.

Čović 1995

B. Čović, Mittelbosnische Fahlerzlagerstätten und die spätkupferzeitliche Metallurgie. In: P. Petrović, S. ĐurĐekanović, B. Jovanović (Eds.), Ancient Mining and Metallurgy in Southeast Europe. Archaeological Institute/Museum of Mining and Metallurgy, Belgrade - Bor 1995, 103-110.

Čović 1999

B. Čović, Prahistorijsko rudarstvo i metalurgija u Bosni i Hercegovini. Stanje i problemi istraživanja. In: Radovi sa simpozijuma rudarstvo i metalurgija Bosne i Hercegovine od prahistorije do početka XX vijeka u Zenici 1973. Zenica 1999, 57-88.

Durman 1983

A. Durman, Metalurgija vučedolskog kompleksa, Opuscula Archaelogica 21, 1983, $7-14$.

ENĂCHIUC 1995

V. ENĂchiuc, Der Bronzfund von Dridu, Kr. Ialomița. In: T. Soroceanu (Ed.), Bronzefunde aus Rumanien I. Prähistorische Archäologie in Südosteuropa 10, Berlin 1995, 279-310.

GARAŠANIN 1975a

А. ГАРАШАНИН, Остава из БрестовиКа I-V. In: М. ГАРАШАНИН, Н. ТАсић (Eds.), Праисторијске оставе у Србији и Војводини I, Археолошка грађа Србије. Belgrade 1975, 8-14.

GARAŠANIN 1975b

А. ГАрашанин, Остава из Руаника. In: М. ГАрашанин, Н. ТАСИћ (Eds.), Праисторијске оставе у Србији и Војводини I, Археолошка грађа Србије. Belgrade 1975, 90-93.

Gavranović 2011

M. Gavranović, Die Spätbronze- und Früheisenzeit in Bosnien. Universitätsforschungen zur prähistorischen Archäologie 195, Bonn 2011.

GaVRANOVIĆ 2013

M. Gavranović, Urnenfelderzeitliche Gussformen aus dem westlichen Balkan. In: S. Berecki, R. Nemeth, B. Rezi (Eds.), Bronze Age Craftsmen in the Carpathian Basin. Proceedings of the International Colloquium from Târgu Mures $\left(5^{\text {th }} 7^{\text {th }}\right.$ October 2012), Târgu Mures 2013, 149-167. 
GAVRANOVIĆ in press

M. GAVRANOvić, Überregionale Netzwerke und lokale Distribution: Verteilungsmuster einiger Bronzeobjekte im westlichen Balkan während der jüngeren und späten Urnenfelderzeit. In: D. LožNJak Dizdar, M. Dizdar, (Eds.), Late Urnfield Culture between the Eastern Alps and the Danube. Proceedings of the International Conference in Zagreb, 7.-8. November 2013. Zagreb in press.

GAVRANOVIĆ, JAŠAREVIĆ 2016

M. Gavranović, A. Jašarević, Neue Funde der Spätbronzezeit aus Nordbosnien, Prilozi Instituta za arheologiju u Zagrebu 34, 2016, 135-178.

GaVRanović, SEJFuli 2016

M. Gavranović, A. SJefuli, Einige bislang unpublizierte Bronzefunde aus dem Lašvatal in Zentralbosnien, Godišnjak Centra za balkanološka ispitivanja 44, 2016, 67-95.

Giumlia-Mair 2009

A. Giumlia-Mair, Ancient metallurgical traditions and connections around the Caput Adriae, Journal of Mining and Metallurgy 45/2, 2009, 149-163.

GLOGOVIĆ 2003

D. GLOGOVIĆ, Fibeln im kroatischen Küstengebiet: (Istrien, Dalmatien). Prähistorische Bronzefunde XIV/13, Stuttgart 2003.

Govedarica, Pernicka, Rittershoffer 1995

B. Govedarica, E. Pernicka, K. F. Rittershofer, Neue Metallanalysen aus dem Westbalkangebiet. In: P. Petrović, S. ĐurĐekanović, B. Jovanović (Eds.), Ancient Mining and Metallurgy in Southeast Europe. Archaeological Institute, Museum of Mining and Metallurgy, Belgrade - Bor 1995, 265-279.

HaMPel 1886

J. HAmpeL, A bronzokor emlékei Magyarhonban I / Altertümer der Bronzezeit in Ungarn. Budapest 1886.

HaNSEN 1994

S. HANSEN, Studien zu den Metalldeponierungen während der älteren Urnenfelderzeit zwischen Rhônental und Karpatenbecken. Universitätsforschungen zur prähistorischen Archäologie 21, Bonn 1994.

HaRding 1995

A. Harding, Die Schwerter im ehemaligen Jugoslawien. Prähistorische Bronzefunde IV/14, Stuttgart 1995.

Ноок 2007

D. Ноок, The composition and technology of selected Bronze Age and Early Iron Age copper alloy artefacts from Italy. In: A. M. Bietti Sestieri, E. Macnamara (Eds.), Prehistoric Metal Artefacts from Italy (3500-720 BC) in the British Museum. London 2007, 308-323.

Hrvatović 1999

H. Hrvatović, Geological guidebook through Bosnia and Herzegovina, Geološki glasnik 24, 1999, 203.

JACANOVIĆ, RADOJČIĆ 2003

А. ЈАЦАновић, Н. РАдојчић, Праисторијска остава металних предмета из сема Шетоње коА Петровца на Ммави, Viminacivm 13-14, 2003, 7-45.

JOCKENHÖVEL 1971

A. Jockenhövel, Die Rasiermesser in Mitteleuropa. Prähistorische Bronzefunde VIII/1, Munich 1971.

Jovanović 2010

D. Jovanović, Ostave vršačkog gorja: Markovac-Grunjac. Vršac 2010.
Jung, Mehofer 2013a

R. Jung, M. Mehofer, Mycenaean Greece and Bronze Age Italy: cooperation, trade or war? Archäologisches Korrespondenzblatt 43, 2013, 175-193.

Jung, Mehofer 2013b

R. Jung, M. Mehofer, Analisi archeologiche ed archeometriche di una Punta di giavellotto del BR. In: A. Cazzella, M. MoscoLONI, G. Recchia, Coppa Nevigata e l'area umida alla foce del Candelaro durante l'età del Bronzo. Foggia, 2013, 453-456.

Jung, Mehofer, Pernicka 2011

R. Jung, M. Mehofer, E. Pernicka, Metal exchange in Italy from the Middle to the Final Bronze Age $\left(14^{\text {th }}-11^{\text {th }}\right.$ cent. BCE). In: P. P. Betancourt, S. C. Ferrence (Eds.), Metallurgy: Understanding How, Learning Why. Prehistory Monographs 29, Philadelphia 2011, 231-248.

Junghans, SANGmeister, Schröder 1960

S. Junghans, E. SAngmeister, M. Schröder, Metallanalysen kupferzeitlicher und frühbronzezeitlicher Bodenfunde aus Europa. Studien zu den Anfängen der Metallurgie 1, Berlin 1960.

Junghans, SANGmeister, Schröder 1968a

S. Junghans, E. Sangmeister, M. Schröder, Kupfer und Bronze in der frühen Metallzeit Europas: Die Metallgruppen beim Stand von 12000 Analysen. Studien zu den Anfängen der Metallurgie 2/1, Berlin 1968.

Junghans, SANgmeister, Schröder 1968b

S. Junghans, E. Sangmeister, M. Schröder, Kupfer und Bronze in der frühen Metallzeit Europas: Tafeln, Tabellen, Diagramme, Karten. Studien zu den Anfängen der Metallurgie 2/2, Berlin 1968.

Junghans, SANGMEISTER, SCHröDER 1968c

S. Junghans, E. Sangmeister, M. Schröder, Kupfer und Bronze in der frühen Metallzeit Europas: Katalog der Analysen Nr. 985 - 10 040. Studien zu den Anfängen der Metallurgie 2/3, Berlin 1968.

Junghans, SANGmeister, Schröder 1974

S. Junghans, E. SAngmeISTer, M. Schröder, Kupfer und Bronze in der frühen Metallzeit Europas: Katalog der Analysen Nr. $10041-$ 22000 (mit Nachuntersuchungen der Analysen Nr. 1-10 040). Studien zu den Anfängen der Metallurgie 2/4, Berlin 1974.

JuRKOVIĆ 1958

I. JURKović, Kasiterit, stamin i molibdenit u rudnoj pojavi Vrtlasce kod Klisca, Geološki glasnik 4, 1958, 304-320.

Jurković, HRVATOvić 2014

I. JuRKović, H. Hrvatović, Geochemical characteristics and genesis of Mačje Jame and Vranjski Potok: As-Cu-Iron occurrences west and southwest of the town Busovača, Mid-Bosnian Schist Mountains (MBSM), Geologia Croatica 67/2, 2014, 145-161.

KARAVANIĆ 2006

S. Karavanić, Metallverarbeitung und -produktion in der Siedlung Mačkovac-Crišnjevi (Nova Gradiška), Prilozi Instituta za arheologiju u Zagrebu 23, 2006, 29-52.

KARAVANIĆ 2009

S. Karavanić, The Urnfield Culture in continental Croatia. BAR International Series 2036, Oxford 2009.

KATZER 1905

F. Katzer, Über die Quarzporphyre der Vranica planina in Bosnien und über einen Fund von Rillenstein in einem alten Bergbau am Westfuße desselben Gebirges, Centralblatt für Mineralogie, Geologie und Paläontologie, 1905, 366-377. 


\section{Kemenzei 1984}

T. Kemenzei, Die Spätbronzezeit Ungarns. Archaeologia Hungarica 51, Budapest 1984.

\section{KNEZ 1958}

T. KNEz, Das Depot aus Osredak, Glasnik Zemaljskog muzaj u Sarajevu 13, 1958, 255-262.

KÖNIG 2004

P. KÖNIG, Spätbronzezeitliche Hortfunde aus Bosnien und der Herzegowina. Prähistorische Bronzefunde XX/11, Stuttgart 2004.

LudAJIĆ 2010

N. LudAJić, Sječkovo, Glasnik Zemaljskog muzeja u Sarajevu 52, 2010, 115-139.

Lutz, Pernicka 1996

J. Lutz, E. Pernicka, Energy dispersive X-ray fluorescence analysis of ancient copper alloys: empirical values for precision and accuracy, Archaeometry 38, 1996, 313-323.

MARIĆ 1964

Z. MArić, Donja Dolina, Glasnik Zemaljskog muzeja u Sarajevu 19, 1964, 5-128.

MAYer 1977

E. F. Mayer, Die Äxte und Beile in Österreich. Prähistorische Bronzefunde IX/9, Stuttgart 1977.

Mehofer 2011

M. Mehofer, Die Kammhelme vom Typ Pass Lueg: Archäologische und archäometallurgische Untersuchungen zur spätbronzezeitlichen Handwerkstechnik. In: A. LipPert (Ed.), Die zweischaligen ostalpinen Kammhelme und verwandte Helmformen der späten Bronze- und frühen Eisenzeit. Archäologie in Salzburg 6, Salzburg 2011, 119-130.

MikLik-Lozuk 2009

L. Miklık-Lozuk, Ostave kasnog brončanog doba iz Poljanaca. Slavonski Brod 2009.

Mozsolics 1985

A. Mozsolics, Bronzefunde aus Ungarn: Depotfundhorizonte Aranyos, Kurd und Gyermely. Budapest 1985.

Niederschlag et al. 2003

E. Niederschlag, E. Pernicka, T. Seifert, M. Bartelheim, The determination of lead isotope ratios by multiple collector ICPMS: a case study of Early Bronze Age artefacts and their possible relation with ore deposits of the Erzgebirge, Archaeometry 45/1, 2003, 61-100.

NorThOVER 1989

J. P. Northover, Properties and use of arsenic - copper alloys. In: A. Hauptmann, E. Pernicka, G. A. Wagner, (Eds.), Old World Archaeometallurgy, Der Anschnitt Beiheift 7. Veröffentlichungen aus dem Deutschen Bergbau-Museum 44, Bochum 1989, 111-117.

Novotná 1970

M. Novotná, Die Äxte und Beile in der Slowakei. Prähistorische Bronzefunde IX/3, Munich 1970.

Palinkaš, ŠošTarić, Palinkaš 2008.

L. A. Palinkaš, S. B. Šoštarić, S. S. Palinkaš, Metallogeny of the northwestern and central Dinarides and southern Tisia, Ore Geology Reviews 34/3, 2008, 501-520.

PAŠALIĆ 1954

E. PAŠAlić, O antičkom rudarstvu u Bosni i Hercegovini, Glasnik Zemaljskog muzeja u Sarajevu 9, 1954, 52-71.

PERNICKA 1987

E. Pernicka, Erzlagerstätten in der Ägäis und ihre Ausbeutung im Altertum. Geochemische Untersuchungen zur Herkunftsbestimmung archäologischer Metallobjekte, Jahrbuch des Römisch-Germanischen Zentralmuseums 34, 1987, 607-714.
PERnicka et al. 1993

E. Pernicka, F. Begemann, S. Schmitt-Strecker, G. A. Wagner, Eneolithic and Early Bronze Age copper artefacts from the Balkans and their relation to Serbian copper ores, Praehistorische Zeitschrift 68, 1993, 1-54.

Pernicka et al. 1997

E. Pernicka, F. Begemann, S. Schmitt-Strecker, H. Todorova, I. Kuleff, Prehistoric copper in Bulgaria: its composition and provenance, Eurasia Antiqua 3, 1997, 41-180.

PERNICKA 1999

E. Pernicka, Trace element fingerprinting of ancient copper: a guide to technology or provenance? In: S. M. M. Young, A. M. PolLARD, P. Budd, R.A. Ixer (Eds.), Metals in Antiquity. BAR International Series 792, Oxford 1999, 163-171.

PERNICKA 2014

E. Pernicka, Provenance determination of archaeological metal objects: short history of provenance analysis of archaeological metal objects. In: B. W. Roberts, C. P. Thornton (Eds.), Archaeometallurgy in Global Perspective, New York 2014, 239-268.

Pernicka et al. 2016

E. Pernicka, B. Nessel, M. Mehofer, E. Safta, Lead isotope analyses of metal objects from the Apa hoard and other Early and Middle Bronze Age items from Romania, Archaeologia Austriaca $100,2016,57-86$.

Petrescu-Dîmbovița 1977

M. Petrescu-Dîmbovița, Depozitele de bronzuri din România. Bucharest 1977.

Petrescu-Dîmbovița 1978

M. Petrescu-Dîmbovița, Die Sicheln in Rumänien mit Corpus der jung- und spätbronzezeitlichen Horte Rumäniens. Prähistorische Bronzefunde XVIII/1, Munich 1978.

Popović 1975

A. Поповић, Остава из Шимановаца. In: М. ГАРАшАнин, Н. ТАСић (Eds.), Праисторијске оставе у Србији и Војводини I, Археолошка грађа Србије. Belgrade 1975, 43-52.

Popović 1994

А. ПоПовић, Остава из Аоњих Петроваца. In: М. ГАРАшАнин, H. ТАСић (Eds.), Праисторијске оставе у Србији и Војводини II, Археолошка грађа Србије. Belgrade 1994, 25-35.

PRIMAS 1986

M. Primas, Die Sicheln in Mitteleuropa I: Österreich, Schweiz, Süddeutschland. Prähistorische Bronzefunde XVIII/2, Stuttgart 1986.

RADIMSKÝ 1893

W. RADimskŕ, Die römische Befestigung auf der Crkvenica und das Castrum bei Doboj, Wissenschaftliche Mitteilungen aus Bosnien und Herzegowina 1, 1893, 262-273.

RADIMSKÝ 1897

W. Radimskŕ, Der prähistorische Pfahlbau von Ripač bei Bihać, Wissenschaftliche Mitteilungen aus Bosnien und Herzegowina $5,1897,20-123$.

RAMOVIĆ 1999

M. Ramović, Nalazišta ruda zlata, bakra, kalaja, željeza, srebra, olova, žive, antimona i arsena u SR BiH. In: Radovi sa simpozijuma rudarstvo i metalurgija Bosne i Hercegovine od prahistorije do početka XX vijeka u Zenici 1973. Zenica 1999, 9-20.

RAUNIG 1982

B. Raunig, Grob ranog željeznog doba iz Ostrožca kod Cazina, Glasnik Zemaljskog muzeja u Sarajevu 37, 1982, 2-13.

Ř́íHOVsKÝ 1983

J. ŘíhovskÝ, Nadeln in Westungarn. Prähistorische Bronzefunde XIII/10, Stuttgart 1983. 
Ř́́HOVSKÝ 1992

J. ŘíHovskŕ, Die Äxte, Beile, Meisel und Hammer in Mähren. Prähistorische Bronzefunde IX/17, Stuttgart 1992.

SPERBER 2004

L. Sperber, Zur Bedeutung des nördlichen Alpenraumes für die spätbronzezeitliche Kupferversorgung in Mitteleuropa: mit besonderer Berücksichtigung Nordtirols. In: G. WeIsGerber, G. Goldenberg (Eds.), Alpenkupfer - Rame delle Alpi, Der Anschnitt Beiheft 17. Veröffentlichungen aus dem Deutschen Bergbau-Museum 122, Bochum 2004, 303-345.

Stos-Gale, Gale, Houghton, Speakman 1995

Z. Stos-Gale, N. Gale, J. Houghton, R. Speakman, Lead isotope data from the Isotrace Laboratory, Oxford: Archaeometry Data Base 1, ores from the western Mediterranean, Archaeometry 37, 1995, 407-415.

TARBAY 2014

G. Tarbay, Late Bronze Age depot from the foothills of the Pilis Mountains. Dissertationes Archaeologicae ex Instituto Archaeologico Universitatis de Rolando Eötvös Nominatae, Ser. 3. No. 2, Budapest 2014, 179-299.

TASIĆ 1975

Н. ТАСић, Бронзана остава из Јакова - Економија Сава. In: М. ГАРАШАНИН, Н. ТАСИћ (Еds.), Праисторијске оставе у Србији и Војводини I, Археолошка грађа Србије. Belgrade 1975, 27-34.

Trampuž-Orel 1996

N. Trampuž-Orel, Spektrometrične raziskave depojskih najdbe pozne bronaste dobe / Spectrometric Reasearch of the Late Bronze Age Hoard finds. In: B. TeRžAn (Ed.), Depojske in posamezne kovinske najdbe bakrene in bronaste dobe na Slovenskem II / Hoards and Individual Metal Finds from the Eneolithic and Bronze Ages in Slovenia II. Catalogi et Monographiae 30, Ljubljana 1996, 165-243.

Trampuž-Orel 1999

N. Trampuž-Orel, Archaeometallurgic investigations in Slovenia: a history of research on non-ferrous metals, Arheološki Vestnik 50, 1999, 407-429.

TRUHELKa 1904

Ć. Trunelka, Der vorgeschichtliche Pfahlbau im Savabette bei Donja Dolina (Bezirk Bosnisch - Gradiška), Wissenschaftliche Mitteilungen aus Bosnien und Herzegowina 9, 1904, 3-171.

TruHelKa 1907

Ć. Truhelka, Prehistorijski nalazi u Bosni i Hercegovini (Nalazi brončane dobi iz Tešnja i okolice), Glasnik Zemaljskog muzeja Bosne i Hercegovin 19, 1907, 62-75.

VASIĆ 1982

R. VASIĆ, Spätbronzezeitliche und älterhallstattzeitliche Hortfunde im östlichen Jugoslawien. In: B. HÄNsEL (Ed.), Südosteuropa zwischen 1600 und 1000 v. Chr. Prähistorische Archäologie in Südosteuropa 1, Berlin 1982, 267-285.

VAsIĆ 1994

R. VASIĆ, Die Sicheln im Zentralbalkan: (Vojvodina, Serbien, Kosovo und Makedonien). Prähistorische Bronzefunde XVIII/8, Stuttgart 1994.

VASIĆ 2015

R. VAsIĆ, Die Lanzen- und Pfeilspitzen im Zentralbalkan (Vojvodina, Serbien, Kosovo, Mazedonien). Prähistorische Bronzefunde V/8, Stuttgart 2015.

vON BRUnN 1968

W. A. von Brunn, Mitteldeutsche Hortfunde der jüngeren Bronzezeit. Römisch-Germanische Forschungen 29, Berlin 1968.
VINSKI-GASPARINI 1973

K.VINSKI-GASPARINI, Kultura polja sa žarama u sjevernoj Hrvatskoj. Zadar 1973.

WANG, OTTAWAY 2004

Q. WANG, B. ОтtAWAy, Casting experiments and microstructure of archaeologically relevant bronzes. BAR International Series 1331, Oxford 2004.

WANZEK 1989

B. WANZEK, Die Gußmodel für Tüllenbeile im südöstlichen Europa. Universitätsforschungen zur prähistorischen Archäologie 2, Bonn 1989.

WANZEK 1997

B. WANZEK, Nordica im bronzezeitlichen Südosteuropa. In: C. BECKer, M. L. Dunkelmann, C. Metzner-Nebelsick, H. PeterRöcher, M. Roeder, B. Teržan (Eds.), Xpóvos, Festschrift für Bernhard Hänsel. Studia Honoria I, Berlin 1997, 527-541.

WeBER 1996

C. Weber, Die Rasiermesser in Südosteuropa: (Albanien, BosnienHerzegowina, Bulgarien, Griechenland, Kroatien, Mazedonien, Montenegro, Rumänien, Serbien, Slowenien und Ungarn). Prähistorische Bronzefunde VIII/5, Stuttgart 1996.

Žeravica 1993

Z. ̌̌eravica, Äxte und Beile aus Dalmatien und anderen Teilen Kroatiens, Montenegro, Bosnien und Herzegowina. Prähistorische Bronzefunde IX/18, Stuttgart 1993.

Mario Gavranović
Institute for Oriental and European Archaeology (OREA)
Austrian Academy of Sciences
Hollandstraße 11-13
1020 Vienna
Austria
mario.gavranovic@oeaw.ac.at

Mathias Mehofer

VIAS - Vienna Institute for Archaeological Science Archaeometallurgy University of Vienna Franz Klein-Gasse 1 1190 Vienna Austria matbias.mehofer@univie.ac.at Aleksandar Jašarević
Regional Museum Doboj
Bosnia-Herzegovina
aleksandar_jas@yahoo.com Ajla Sejfuli Museum Travnik Bosnia-Herzegovina asejfuli@gmail.com 